\title{
Stratospheric ozone loss in the Arctic winters between 2005 and 2013 derived with ACE-FTS measurements
}

\author{
Debora Griffin ${ }^{1}$, Kaley A. Walker ${ }^{1,2}$, Ingo Wohltmann ${ }^{3}$, Sandip S. Dhomse ${ }^{4,5}$, Markus Rex ${ }^{3}$, \\ Martyn P. Chipperfield ${ }^{4,5}$, Wuhu Feng ${ }^{4,6}$, Gloria L. Manney ${ }^{7,8}$, Jane Liu ${ }^{9,10}$, and David Tarasick ${ }^{11}$ \\ ${ }^{1}$ Department of Physics, University of Toronto, Toronto, Ontario, M5S 1A7, Canada \\ ${ }^{2}$ Department of Chemistry, University of Waterloo, Waterloo, Ontario, N2L 3G1, Canada \\ ${ }^{3}$ Alfred Wegener Institute for Polar and Marine Research, 14401 Potsdam, Germany \\ ${ }^{4}$ School of Earth and Environment, University of Leeds, Leeds, LS2 9JT, UK \\ ${ }^{5}$ National Centre for Earth Observation, University of Leeds, Leeds, LS2 9JT, UK \\ ${ }^{6}$ National Centre for Atmospheric Science, University of Leeds, Leeds, LS2 9JT, UK \\ ${ }^{7}$ NorthWest Research Associates, Socorro, New Mexico, USA \\ ${ }^{8}$ Department of Physics, New Mexico Institute of Mining and Technology, Socorro, New Mexico 87801, USA \\ ${ }^{9}$ Department of Geography and Program in Planning, University of Toronto, Toronto, Ontario, M5S 3G3, Canada \\ ${ }^{10}$ Nanjing University, Nanjing, Jiangsu, 210023, China \\ ${ }^{11}$ Science and Technology Branch, Environment and Climate Change Canada, Toronto, Ontario, M3H 5T3, Canada
}

Correspondence: Kaley A. Walker (kaley.walker@utoronto.ca)

Received: 18 November 2017 - Discussion started: 2 January 2018

Revised: 17 September 2018 - Accepted: 1 October 2018 - Published: 16 January 2019

\begin{abstract}
Stratospheric ozone loss inside the Arctic polar vortex for the winters between 2004-2005 and 2012-2013 has been quantified using measurements from the spaceborne Atmospheric Chemistry Experiment Fourier Transform Spectrometer (ACE-FTS). For the first time, an evaluation has been performed of six different ozone loss estimation methods based on the same single observational dataset to determine the Arctic ozone loss (mixing ratio loss profiles and the partial-column ozone losses between 380 and $550 \mathrm{~K}$ ). The methods used are the tracer-tracer correlation, the artificial tracer correlation, the average vortex profile descent, and the passive subtraction with model output from both Lagrangian and Eulerian chemical transport models (CTMs). For the tracer-tracer, the artificial tracer, and the average vortex profile descent approaches, various tracers have been used that are also measured by ACE-FTS. From these seven tracers investigated $\left(\mathrm{CH}_{4}, \mathrm{~N}_{2} \mathrm{O}, \mathrm{HF}\right.$, OCS, CFC-11, CFC-12, and CFC-113), we found that $\mathrm{CH}_{4}, \mathrm{~N}_{2} \mathrm{O}, \mathrm{HF}$, and CFC-12 are the most suitable tracers for investigating polar stratospheric ozone depletion with ACE-FTS v3.5. The ozone loss estimates (in terms of the mixing ratio as well as total column ozone) are generally in good agreement between the differ-
\end{abstract}

ent methods and among the different tracers. However, using the average vortex profile descent technique typically leads to smaller maximum losses (by approximately 15-30 DU) compared to all other methods. The passive subtraction method using output from CTMs generally results in slightly larger losses compared to the techniques that use ACE-FTS measurements only. The ozone loss computed, using both measurements and models, shows the greatest loss during the 2010-2011 Arctic winter. For that year, our results show that maximum ozone loss (2.1-2.7 ppmv) occurred at $460 \mathrm{~K}$. The estimated partial-column ozone loss inside the polar vortex (between 380 and $550 \mathrm{~K}$ ) using the different methods is 66103, 61-95, 59-96, 41-89, and 85-122 DU for March 2005, $2007,2008,2010$, and 2011, respectively. Ozone loss is difficult to diagnose for the Arctic winters during 2005-2006, 2008-2009, 2011-2012, and 2012-2013, because strong polar vortex disturbance or major sudden stratospheric warming events significantly perturbed the polar vortex, thereby limiting the number of measurements available for the analysis of ozone loss. 


\section{Introduction}

Arctic ozone column loss is extremely variable in the winter and springtime and can range from near zero to about 150 DU (e.g. Manney et al., 2011; Kuttippurath et al., 2012; Livesey et al., 2015), unlike in the Antarctic, where ozone loss is typically large and shows smaller interannual variability (e.g. WMO, 2014). The large interannual variability is mostly caused by the Arctic meteorology (e.g. Andrews, 1989; Schoeberl and Hartmann, 1991; Schoeberl et al., 1992). Due to topography and land-sea contrasts, wintertime wave activity that drives stratospheric circulation is much stronger and more variable in the Northern Hemisphere $(\mathrm{NH})$ than in the Southern Hemisphere (SH; e.g. Weber et al., 2003). Therefore, the polar vortex in the $\mathrm{NH}$ is typically weaker and more variable from year-to-year than the polar vortex of the SH. Climatologically, the Arctic lower stratospheric polar vortex forms in November and breaks up in April, but break-up dates can be much earlier (when there are major sudden stratospheric warmings - SSWs - during which temperatures increase rapidly and mid-stratospheric zonal mean winds reverse) or later (in particularly quiescent winters; WMO, 2014). If, however, the polar vortex remains stable and temperatures within it are low, polar stratospheric clouds (PSCs) can form (e.g. Steele et al., 1983; Toon et al., 1986; Crutzen and Arnold, 1986; Lowe and MacKenzie, 2008). PSCs that contain primarily ice particles (Steele et al., 1983) typically form at temperatures below $188 \mathrm{~K}$ (Poole and McCormick, 1988). Other PSCs are composed of either nitric acid trihydrate (NAT) particles or a super-cooled ternary solution (STS), a mixture of $\mathrm{HNO}_{3}-\mathrm{H}_{2} \mathrm{SO}_{4}-\mathrm{H}_{2} \mathrm{O}$ particles, and can form at much higher temperatures around 195-197 K (e.g. Crutzen and Arnold, 1986; Toon et al., 1986; Arnold, 1992; Carslaw et al., 1994; Pitts et al., 2007, 2009, 2013; Spang et al., 2017). Since wintertime temperatures in the Arctic polar regions are higher than those in the Antarctic winter, most PSCs in the Arctic are nitric-acid containing ones that form at higher temperatures (Solomon, 1999, and references therein). Chlorine activation is triggered on the surface of PSCs and/or cold binary aerosols (e.g. Portmann et al., 1996; Drdla and Müller, 2012; WMO, 2014), releasing chlorine molecules. When the chlorine molecules are exposed to sunlight, these molecules break into chlorine radicals that are responsible for springtime polar catalytic ozone depletion (e.g. McElroy et al., 1986; Molina and Molina, 1987). For polar ozone loss, low temperatures are required, but they also need to last long enough into the period when sufficient sunlight is available to drive the ozone loss. Thus, the amount of yearly ozone loss in the Arctic is strongly influenced by the temperature within the polar vortex and whether an SSW event has occurred.

In recent years, there have been several major SSWs in the Arctic; the most pronounced SSW events occurred in January 2006 (Manney et al., 2008a; Coy et al, 2009; Manney et al., 2009a), January 2009 (Labitzke and Kunze, 2009; Manney et al., 2009b), January and February 2010, and January 2013 (Manney et al., 2015; Coy and Pawson, 2015). In those years, the polar vortex broke up in January; hence no significant springtime chemical ozone depletion was detected. During the 2010 winter, the polar vortex was highly influenced by dynamics and mixing due to a major SSW; the vortex split into two parts in mid-December 2009, these two parts reunited in January, and in mid-February, the vortex split again into two parts that were reunited at the beginning of March (e.g. Dörnbrack et al., 2012; Kuttippurath and Nikulin, 2012; Wohltmann et al., 2013). In January 2012, a very strong polar vortex disturbance occurred (Berhard et al., 2012; Chandran et al., 2013). In the Arctic spring, if a polar vortex exists, the ozone mixing ratio inside that polar vortex peaks at around $3.5 \mathrm{ppmv}$, between approximately 450 and $475 \mathrm{~K}$, in the absence of chemical ozone depletion (based on ACE-FTS measurements inside the polar vortex in January). During the winters of 2004-2005 (Manney et al., 2006; Jin et al., 2006; Kuttippurath et al., 2010), 2006-2007 (Kuttippurath et al., 2010), and 2007-2008 (Kuttippurath et al., 2010), the Arctic polar vortex was strong, and ozone depletion on the order of 1.5 ppmv (around $40 \%$ loss) occurred in the lower stratosphere. In the winter of 2010-2011, a very strong vortex and exceptionally prolonged cold period led to unprecedented Arctic chemical ozone loss (Balis et al., 2011; Manney et al., 2011; Sinnhuber et al., 2011; Adams et al., 2012; Arnone et al., 2012; Isaksen et al., 2012; Kuttippurath et al., 2012; Lindenmaier et al., 2012). The chemical ozone loss peaked by the end of March at around $2.5 \mathrm{ppmv}$ (around $70 \%$ loss) in the lower stratosphere. The ozone quickly recovered again once the zonal wind relaxed and the polar vortex weakened at the end of March (Isaksen et al., 2012).

In addition to chemical ozone depletion, dynamical processes, such as the descent, mixing of extra-vortex air, and mixing within the polar vortex affect the ozone concentration. Because of the strong dynamical variability of the Arctic polar vortex, quantifying chemical ozone loss is more challenging in the Arctic than in the Antarctic. As such, the effects of chemical loss versus dynamics need to be understood and separated (e.g. Manney et al., 1994a, 1995; Chipperfield and Jones, 1999; Harris et al., 2002; WMO, 2006; Livesey et al., 2015). Several approaches have been developed to estimate the springtime ozone abundance profile that results solely from dynamical processes. The difference between this estimated "passive ozone", which is only influenced by dynamics (and not by chemical processes), and the observed ozone is assumed to be the chemical ozone loss.

Some methods, such as the tracer-tracer correlation approach (e.g. Proffitt et al., 1993; Müller et al., 2001), only require measurements to determine the passive ozone. The tracer-tracer correlation method determines the chemical depletion from the relationship between ozone and a long-lived passive tracer. However, processes that mix extra-vortex air in the polar vortex as well as the descent from higher altitudes are not considered in this approach, and these can change 
the tracer-tracer correlation significantly, thus rendering the tracer-tracer correlation method inaccurate (e.g. Plumb et al., 2000, 2003; Plumb, 2007). Using an artificial tracer (e.g. Esler and Waugh, 2002; Jin et al., 2006) that is constructed (from observed trace gases) to be linearly correlated with ozone can improve the accuracy of the loss estimate. Estimates can also be made by determining the average descent rate inside the polar vortex, obtained from a long-lived tracer, and then estimating the passive ozone abundance (e.g. Manney et al., 2006; Jin et al., 2006). This method can be applied in most years, since the descent is typically the dominant dynamical process in the Arctic vortex. Other methods use chemical transport models (CTMs) to determine the passive ozone profiles, where the ozone chemistry processes are not included in the model run (e.g. Manney et al., 2005; Kuttippurath et al., 2010, 2012; Brakebusch et al., 2013; Wohltmann et al., 2013). The ozone loss can then be estimated from the difference between the modelled passive ozone and the observed (or modelled) ozone. These models also include detailed ozone chemistry, and this output can be used to understand the accuracy of the simulations by comparing with observations.

The focus of this study is to use measurements from the Atmospheric Chemistry Experiment Fourier Transform Spectrometer (ACE-FTS; Bernath et al., 2005) between 2005 and 2013 to compare ozone loss estimates from different methods. Chemical ozone depletion for each spring is estimated using the tracer-tracer correlation method, the artificial tracer approach, the average vortex profile descent technique, the modelled passive ozone subtraction method using a Lagrangian and an Eulerian transport model, and modelled chemical ozone loss using the Eulerian model, SLIMCAT (Chipperfield et al., 2006). Since ACE-FTS provides measurements of many trace gases, several of them are investigated for the tracer correlation and descent approaches. This is the first study to evaluate these different ozone loss estimation methods based on a single dataset. Thus, the purpose of this work is to assess the differences in chemical ozone depletion obtained by different methods without the confounding influence of different trace gas datasets.

This paper is structured as follows. The ACE-FTS instrument and dataset are reviewed in Sect. 2, followed by a description of the methods used to estimate the springtime chemical ozone loss in Sect. 3. The results of the evaluation of the choice of tracer and the different methods are provided in Sect. 4. A comparison of results from this study with previous studies of Arctic ozone loss in spring 2011 is also given in Sect. 4. This is then followed by a summary and conclusions in Sect. 5.

\section{ACE-FTS measurements}

\subsection{ACE-FTS instrument and retrieval algorithm}

The Atmospheric Chemistry Experiment (ACE), on SCISAT, was launched on 12 August 2003, and measurements have been taken since February 2004. The primary instrument on board SCISAT is the ACE-FTS, which measures the spectral region between 750 and $4400 \mathrm{~cm}^{-1}$ at a spectral resolution of $0.02 \mathrm{~cm}^{-1}$. The primary scientific objective of SCISAT is to improve the understanding of polar ozone chemistry (Bernath et al., 2005). Therefore, the orbit of SCISAT was selected such that it provides measurements over the Arctic during the winter and springtime every year. The observation technique used by ACE-FTS is solar occultation, which provides profiles with a vertical resolution between $1.5 \mathrm{~km}$ and $6 \mathrm{~km}$ depending on the beta angle, the angle between the vector from the Earth to the Sun and the satellite velocity vector. Retrievals from the infrared spectra provide profiles for over 30 atmospheric trace gases as well as the meteorological variables of temperature and pressure (Boone et al., 2005). The volume mixing ratio (VMR) of the various trace gases, temperature and pressure profiles used in this study are from the latest retrieval version, ACE-FTS v3.5 (Boone et al., 2013). The uncertainties provided with this dataset for the ACE-FTS profiles are statistical fitting errors from the retrieval algorithm. Systematic errors are not included (Boone et al., 2005). Profiles are retrieved from the top of the clouds up to approximately $150 \mathrm{~km}$. For clear sky conditions, the lower limit of the retrieved profiles can be as low as $5 \mathrm{~km}$.

ACE-FTS ozone has been validated against various other space-borne as well as ground-based instruments. In the lower stratosphere (between approximately 14 and $27 \mathrm{~km}$, the region of interest for this study), generally good agreement with differences of less than $\pm 5 \%$ was found between ACE-FTS v3.5 and the Aura Microwave Limb Sounder (MLS) and the Michelson Interferometer for Passive Atmospheric Sounding (MIPAS) ozone measurements (Sheese et al., 2016). The other ACE-FTS trace gas retrievals that have been used in this study, such as $\mathrm{N}_{2} \mathrm{O}, \mathrm{CFC}-12\left(\mathrm{CCl}_{2} \mathrm{~F}_{2}\right)$, CFC-11 $\left(\mathrm{CCl}_{3} \mathrm{~F}\right), \mathrm{HF}, \mathrm{CH}_{4}, \mathrm{OCS}$, and $\mathrm{CFC}-113$ have also been reported and validated in previous studies. Sheese et al. (2016) have shown that below $27 \mathrm{~km}$ differences between ACE-FTS v3.5 and MLS and MIPAS $\mathrm{N}_{2} \mathrm{O}$ measurements are within $\pm 10 \%$. ACE-FTS $\mathrm{CCl}_{3} \mathrm{~F}$ and $\mathrm{CCl}_{2} \mathrm{~F}_{2}$ have been compared with MIPAS by Eckert et al. (2016), and these species agree better than $15 \%$ for $\mathrm{CCl}_{3} \mathrm{~F}$ and $20 \%$ for $\mathrm{CCl}_{2} \mathrm{~F}_{2}$ in the altitude range of interest. HF has been compared to Halogen Occultation Experiment (HALOE) observations, and differences were within $10 \%$ (Harrison et al., 2016). Some species have not been validated for the latest retrieval product. However, Waymark et al. (2013) have shown general improvements between the previous ACE-FTS v2.2 and the current ACE-FTS v3.0/3.5 across all baseline species. For the ACE-FTS v2.2+updates, the $\mathrm{CH}_{4}$ mixing ratio is be- 
tween $\pm 10 \%$ of other space-borne instruments in the altitude range of interest here (De Mazière et al., 2008). OCS v2.2 has been compared with balloon-borne MkIV and shuttleborne Atmospheric Trace Molecule Spectroscopy (ATMOS) measurements in Barkley et al. (2008) and Velazco et al. (2011), and initial CFC-113 retrievals have been compared with ground-based measurements by Dufour et al. (2005).

\subsection{Dataset used for the ozone loss estimates}

The orbit of ACE-FTS, which was selected to observe the same latitudes in the same month every year, does not cover the whole globe at all times (Bernath et al., 2005). For example, measurements in the Arctic $\left(\geq 65^{\circ} \mathrm{N}\right)$ are taken in approximately late January, all of March, late May, midJuly, mid-September, and early October every year. For the ozone loss assessment in this study, ACE-FTS v3.5 measurements north of $65^{\circ}$ between potential temperatures of 375 and $550 \mathrm{~K}$ are considered. Quality flags, as recommended by Sheese et al. (2015), are used to remove unrealistic outliers and processing errors. Hereby, entire profiles have been removed from the dataset that contained quality flags between 4 and 7, as well as individual observations (within a profile) that contained a quality flag greater than 2 . Version 1.1 of the ACE-FTS data quality flags was used.

Derived meteorological products (DMPs; Manney et al., 2007) are available at each $1 \mathrm{~km}$ tangent altitude within each ACE-FTS occultation. The geographical location can change significantly with tangent altitude for the ACE-FTS measurements. The geographical location of points from an ACEFTS occultation, for altitudes between 15 and $25 \mathrm{~km}$, can vary by up to $0.5^{\circ}(\sim 100 \mathrm{~km})$ depending on the beta angle. The DMPs include information about the potential temperatures, as well as potential vorticity (PV), and are derived from Goddard Earth Observing System (GEOS) version 5.2.0 analyses (GEOS-5; Rienecker et al., 2008).

In this study, ozone loss in March relative to January has been estimated inside the polar vortex. Thus, the ozone loss is estimated over a time period of approximately 1.5 months. Since some chemical ozone depletion can occur as early as December, most studies measure the chemical loss with respect to December. However, no December measurements are available at high latitudes from ACE-FTS; therefore January was selected as the reference. The scaled potential vorticity (sPV; Dunkerton and Delisi, 1986; Manney et al., 1994b) from the DMPs is used to determine where the measurements were taken relative to the polar vortex. For March, measurements with $\mathrm{SPV} \geq 1.6 \times 10^{-4} \mathrm{~s}^{-1}$ are selected as those located inside the polar vortex (Manney et al., 2007, 2008b). However, for January measurements, a more rigorous vortex selection criterion of $\mathrm{sPV} \geq 1.8 \times 10^{-4} \mathrm{~s}^{-1}$ was applied. Since this criterion only considers measurements well inside the edge of the vortex, it reduces the influence of the mixing from the vortex edge region and improves the results of the tracer-tracer method. Both sPV thresholds are toward the inside of the region of strong PV gradients demarking the vortex edge. These criteria have been applied to each method to be consistent throughout.

The time period investigated in this study is between 2005 and 2013. However, ozone depletion could not be determined for all of those years. For example, in 2004, no ACEFTS measurements are available in January; consequently the tracer-tracer correlation, artificial tracer, and average vortex profile descent techniques could not be applied. As discussed in the introduction, during the winters of 2005-2006, 2008-2009, and 2012-2013 major SSW events, and in 20112012, a strong vortex disturbance occurred (e.g. Manney et al., 2008b, 2009b, 2015; Coy et al, 2009); consequently there were not a sufficient number of measurements inside the polar vortex in March to perform the analysis with ACE-FTS. The ozone depletion inside the Arctic polar vortex was estimated for the remaining winters of 2004-2005, 2006-2007, 2007-2008, 2009-2010, and 2010-2011. Note that the ozone loss estimation for the 2009-2010 winter is the most challenging due to the dynamics and associated strong mixing processes in that year.

\section{Different estimation methods used for the polar ozone loss}

\subsection{Tracer-tracer method}

The tracer-tracer correlation method is based on the assumption that the relationships between long-lived tracers are constant inside an isolated polar vortex (e.g. Proffitt et al., 1993; Müller et al., 2001, 2003; Sankey and Shepherd, 2003; Tilmes et al., 2003, 2004). An empirical relation between a tracer and ozone can be estimated inside the vortex prior to a time when chlorine activation would occur. To derive this correlation function, the polar vortex has to be well established and isolated to limit the influence of mixing processes that could be occurring. In the Arctic, this typically occurs in December or January. This "early vortex reference function" provides the relation between the tracer and ozone in a chemically undisturbed environment. The passive ozone (that includes dynamical processes only) can then be estimated from the early vortex reference function and the tracer concentration later in spring. The chemical ozone loss is defined as the difference between the observed ozone and the calculated passive ozone based on the simultaneous tracer measurements. The uncertainty of the estimated ozone depletion due to chlorine activation is calculated from the $\pm 1 \sigma$ standard deviation of the fitted reference function.

As described in Sect. 2.2, measurements taken in January inside the polar vortex are used to quantify the ozone distribution before significant ozone depletion occurs. This dataset is then compared to measurements taken in March, when chemical ozone depletion is most pronounced in the observed ozone profile. This method has been criticized for neglecting 
processes that mix extra-vortex air into the polar vortex (e.g. Plumb et al., 2000, 2003; Plumb, 2007), because it assumes that the polar vortex is isolated, which is not true for all years, especially in the Arctic. On the other hand, some studies observing Arctic ozone loss in the 1999-2000 winter (a winter with an unusually strong polar vortex and thus little mixing) have found that the mixing of mid-latitude air was not a significant contributor to the observed changes (e.g. Richard et al., 2001; Ray et al., 2002). In our study, using the sPV criteria described above, we attempt to limit the influence of mixing of extra-vortex air in our calculation of the early vortex reference function.

The tracer-tracer correlation method also neglects the descent of ozone or the tracer from high altitudes (middle and upper stratosphere and mesosphere) above $550 \mathrm{~K}$ that is not included in our calculation of the early vortex reference function. However, Salawitch et al. (2002) showed that the supply of ozone-depleted air into the top of the vortex did not play a role in the subsequent evolution of the ozone-tracer relation in the 1999-2000 Arctic winter (where the vortex was strong). Mixing of air from top of the Arctic vortex (where mixing ratios are between 3 and 4 ppm Salawitch et al., 2002) into the polar vortex could, however, underestimate the ozone loss of the tracer-tracer method. In a case study for the spring 2003, Müller et al. (2007) showed that the mixing of mesospheric air is likely small and would not lead to an overestimation of the chemical ozone loss. Rex et al. (2002) state that the tracer-tracer correlation represents a lower limit of the true ozone loss in the case of the 1999-2000 Arctic winter (a year with a stable polar vortex).

With the tracer-tracer correlation method, a variety of tracer gases can be used. A tracer is required to be longlived (Plumb and Ko, 1992) and is thus not influenced by chemical processes over a polar season. Since ACE-FTS retrieves profiles for a large number of different trace gases, we have tested six different tracers: $\mathrm{CH}_{4}, \mathrm{HF}, \mathrm{N}_{2} \mathrm{O}, \mathrm{CCl}_{3} \mathrm{~F}$, $\mathrm{CCl}_{2} \mathrm{~F}_{2}$, and OCS. Figure 1 shows the $\mathrm{O}_{3}$-tracer correlation between for these six tracers for the winter and spring of 2011. Displayed are the ACE-FTS measurements in January (black dots) and March (green dots) together with the estimated early vortex reference function (red solid line). There is evidence of a large chemical ozone depletion in March, since the March measurements are far from the estimated reference function. The ozone loss is estimated as the difference between the measurements (green dots) and the early vortex reference function (red line). For the estimation of the early vortex reference function, a fourth order polynomial was fitted for all of the different tracers. Previous studies have used a third- (e.g. Müller et al., 1997) or fourth-order polynomial fit (e.g. Tilmes et al., 2003; Müller et al., 2003; Tilmes et al., 2004). We found that at least a third-order polynomial is required, with little difference between third and fourth order; the fourth order is chosen to be consistent with the more recent publications. The uncertainty of the calculated passive ozone is estimated from the $\pm 1 \sigma$ standard deviation of the fitted linear correlation. The total error of ozone loss is derived from the uncertainty of the passive ozone and the ACEFTS v3.5 statistical fitting error for ozone, which are added in quadrature.

\subsection{Average vortex profile descent technique}

Chemical ozone loss can be estimated by applying average vortex profile descent rates to the observed winter ozone profiles. This determines the approximate vortex average passive ozone profile that would be observed without chemical ozone depletion in spring for an isolated vortex. This method has previously been used by Manney et al. (2006) and Jin et al. (2006), for example, to estimate Arctic ozone loss. The descent rates between January and March are derived at multiple potential temperature levels from the profile of a long-lived tracer. These descent rates are then applied to the winter ozone profile to determine the passive ozone profile in March. This method was originally utilized by estimating the average vortex profile descent rate from $\mathrm{N}_{2} \mathrm{O}$ profiles within the polar vortex, but many tracers can be used for this technique. Here, we have determined the chemical ozone depletion by applying the profile descent rates, between January and March, from six long lived tracers: $\mathrm{CH}_{4}, \mathrm{HF}, \mathrm{N}_{2} \mathrm{O}$, $\mathrm{CCl}_{3} \mathrm{~F}, \mathrm{CCl}_{2} \mathrm{~F}_{2}$, and OCS. Note that this method only allows for the estimation of one vortex averaged passive ozone profile; all other methods applied in this study estimate a passive ozone mixing ratio for each data point in March. Consequently, this method does not consider any changes of the passive ozone levels that can occur throughout March. The uncertainty of the passive ozone is estimated based on the $\pm 1 \sigma$ standard deviation of the average vortex profile descent (which is quite small for the average vortex profile descent technique). To obtain the total uncertainty, the statistical fitting error of the ACE-FTS tracer measurements and the uncertainty of the passive ozone are added in quadrature. This uncertainty estimate is based on statistical errors only and, as such, underestimates the true uncertainty. It is difficult to estimate the true uncertainty in this case because of the unknown effect of ozone resulting from mixing processes that are not considered for the average vortex profile descent technique.

An example for the average ACE-FTS $\mathrm{N}_{2} \mathrm{O}$ profiles inside the polar vortex between January (black line) and March (green line) 2011 is displayed in Fig. 2a. The strongest descent rates occur for high potential temperature levels (approximately $-25 \mathrm{~K} / 1.5$ months), and a very slow descent was observed at $400 \mathrm{~K}$ (approximately $-4 \mathrm{~K} / 1.5$ months). Figure $2 \mathrm{~b}$ displays the observed ozone in January (black dots) and March (green dots) of 2011. The passive ozone profile estimated from the $\mathrm{N}_{2} \mathrm{O}$ average descent rate between January and March is shown as a blue line. The difference between the observed March ozone concentrations and passive ozone profile is the estimate of the chemical ozone loss and is shown as red triangles. Similar figures using the remaining tracers (except for $\mathrm{CCl}_{3} \mathrm{~F}$, as not enough data were available 

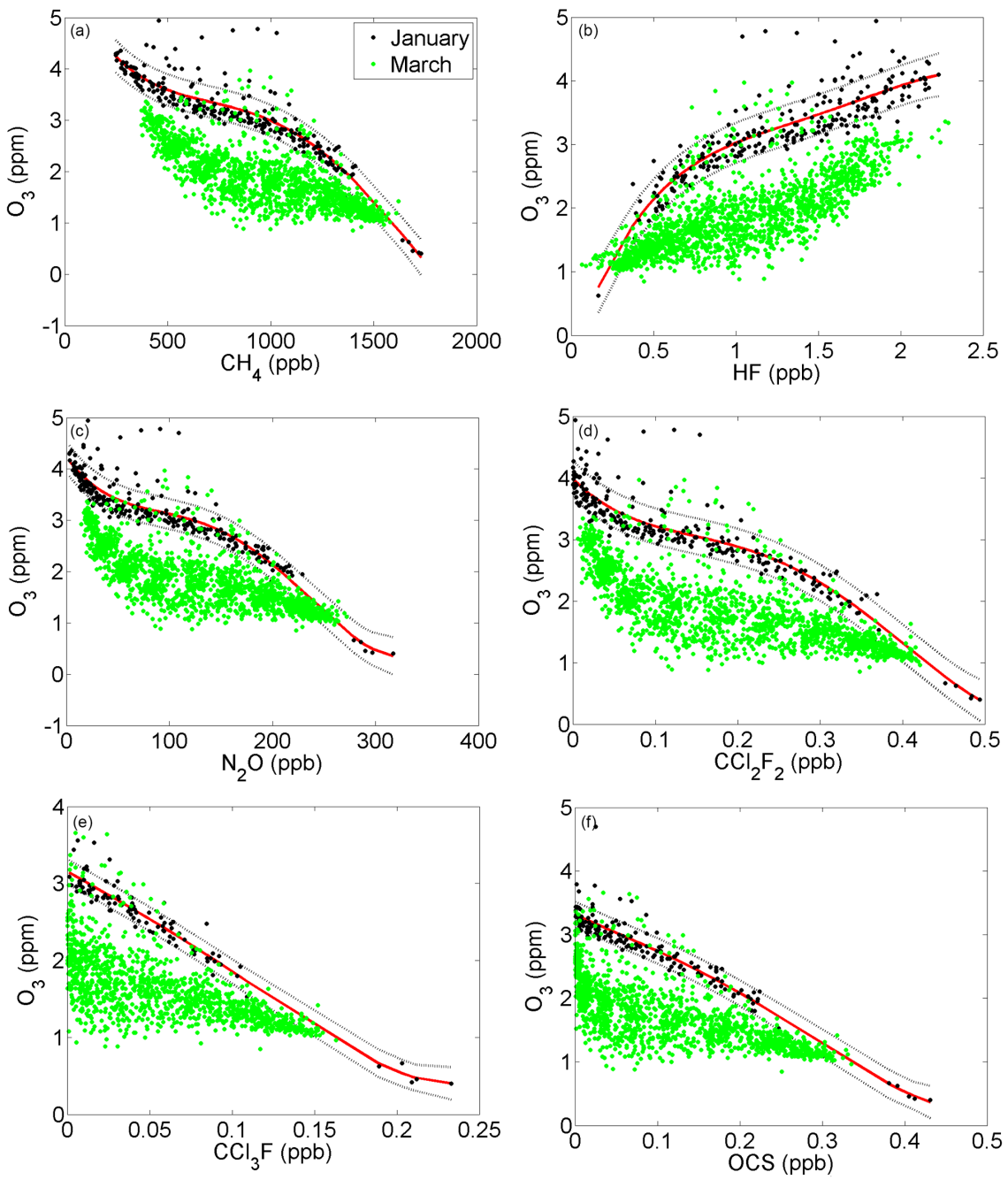

Figure 1. $\mathrm{O}_{3}$-tracer correlation using ACE-FTS measurements inside the polar vortex in January (black dots) and March (green dots) 2011 using (a) $\mathrm{CH}_{4}$, (b) $\mathrm{HF}$, (c) $\mathrm{N}_{2} \mathrm{O}$, (d) $\mathrm{CCl}_{2} \mathrm{~F}_{2}$, (e) $\mathrm{CCl}_{3} \mathrm{~F}$, and (f) OCS as a tracer, in units of volume mixing ratios. The red line shows the estimated early vortex reference function (see text for details) and the dashed black lines indicate the $\pm 1 \sigma$ standard deviation of the fit.

in 2011) can be found in the Supplement (Figs. S1-S4). The plots are very similar for all of the tracers used in this study.

\subsection{Artificial tracer method}

The amount of mixing of extra-vortex air into the Arctic polar vortex varies widely depending on the dynamics of each winter and spring (WMO, 2014). Neglecting mixing processes from the edge of the polar vortex or the mixing of high altitude air (above the ozone maximum) can lead to an underestimation of the chemical ozone loss (e.g. Rex et al., 2002; Müller et al., 2005). One method that provides a correction for both the mixing from the vortex edge and for the descent is the artificial tracer method. This method was first proposed by Esler and Waugh (2002) and uses a "tracer" created from a linear combination of several different trace gases that is linearly correlated with ozone. This linear correlation makes it easier to determine the ozone loss and reduces the impact of mixing, since mixing from the edge of the vortex would only result in "moving" the air parcels along this linear correlation line (Esler and Waugh, 2002). Initially such an artificial tracer method was used by Esler and Waugh (2002) to estimate denitrification inside the Arctic polar vortex. However, this same method can be applied for estimating the chemical ozone loss, as was done by Jin et al. (2006). While it reduces the error from mixing of air near the vortex edge, this method, however, does not account for the mixing of extra-polar vortex air into the vortex. The artificial tracer, established from observations inside the polar vortex, does not follow the same linear correlation outside the polar vortex (Jin et al., 2006).

Different combinations of tracers can be used to estimate an artificial tracer. Here, we have tested four different combi- 

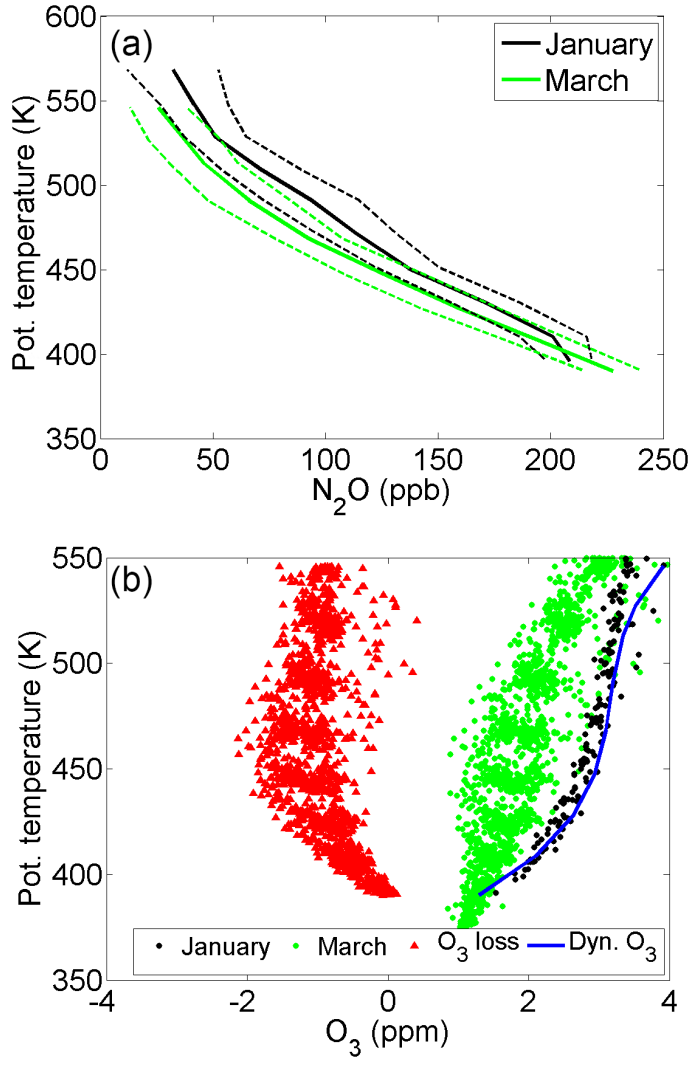

Figure 2. (a) shows the monthly average $\mathrm{N}_{2} \mathrm{O}$ profiles observed by ACE-FTS inside the polar vortex in January (black line) and March (green line) 2011 together with the respective standard deviations (shown as dashed lines). (b) displays the observed ACE-FTS ozone in January (black dots) and March (green dots) 2011, the passive ozone (blue line) for March 2011, estimated from the average vortex profile descent from $\mathrm{N}_{2} \mathrm{O}$, and the ozone loss (red triangles; the difference between observed and average passive ozone in March).

nations that were employed by Esler and Waugh (2002) and Jin et al. (2006). These tracers include a combination of

1. $\mathrm{N}_{2} \mathrm{O}, \mathrm{CH}_{4}, \mathrm{CCl}_{3} \mathrm{~F}$, and $\mathrm{CCl}_{2} \mathrm{~F}_{2}$ (Esler and Waugh, 2002);

2. $\mathrm{N}_{2} \mathrm{O}, \mathrm{CH}_{4}, \mathrm{CCl}_{3} \mathrm{~F}$, and $\mathrm{CFC}-113$ (Esler and Waugh, 2002);

3. $\mathrm{N}_{2} \mathrm{O}, \mathrm{CH}_{4}$, and $\mathrm{CCl}_{2} \mathrm{~F}_{2}$ (Esler and Waugh, 2002);

4. $\mathrm{N}_{2} \mathrm{O}, \mathrm{CH}_{4}, \mathrm{OCS}$, and $\mathrm{CCl}_{3} \mathrm{~F}$ (Jin et al., 2006).

These artificial tracers will be referred to, in this paper, as Tracer 1, Tracer 2, Tracer 3, and Tracer 4, respectively. To estimate the artificial tracer that is linearly correlated with ozone, ACE-FTS measurements inside the polar vortex in January are employed. The correlation is then used to estimate the passive ozone levels that would be observed without chemical ozone depletion in March. The difference between the observed ozone and estimated passive ozone equals the chemically depleted ozone between January and March. The linear combination needed to obtain the artificial tracer is estimated for each year, since the trace gas concentrations and the tracer-ozone correlation of these can vary from year-toyear. It is assumed that the linear combination is constant on a shorter time frame, e.g. within the polar vortex of one winter (Esler and Waugh, 2002). This combination was found to be similar (typically with constants on the same order of magnitude, see Supplement Tables S1 and S2) in some years between 2004 and 2013, but it was not the same for each year. The uncertainty of the calculated passive ozone is estimated from the $\pm 1 \sigma$ standard deviation of the fitted linear correlation. The total error of ozone loss is derived from the uncertainty of the passive ozone and the ACE-FTS v3.5 statistical fitting error for ozone, which are added in quadrature.

An example of the artificial tracer correlation for all four artificial tracers is shown in Fig. 3. The data shown are mixing ratios inside the polar vortex during January (black dots) and March (green dots) 2011. While Tracer 1, Tracer 2, and Tracer 4 show a linear correlation with ozone and a small standard deviation, Tracer 3 is not quite linearly correlated and consequently has a larger uncertainty. There is strong evidence in these figures of the chemical ozone depletion in 2011, since the ozone levels in March are very low compared to January and are not linearly correlated with the artificial tracers. The passive ozone is estimated from the linear fit by assuming that without any chemical ozone depletion, the ozone levels should still follow this correlation in March. The linear combinations used to estimate the artificial tracers for the 2011 dataset, are

$$
\begin{aligned}
{[\text { Tracer1 }]_{\mathrm{ppb}}=} & 9.34 \times 10^{-4}\left[\mathrm{CH}_{4}\right]_{\mathrm{ppb}}-7.45 \times 10^{-4}\left[\mathrm{~N}_{2} \mathrm{O}\right]_{\mathrm{ppb}} \\
& -3.41 \times 10^{-3}\left[\mathrm{CCl}_{2} \mathrm{~F}_{2}\right]_{\mathrm{ppt}}-9.46 \\
& \times 10^{-3}\left[\mathrm{CCl}_{3} \mathrm{~F}\right]_{\mathrm{ppt}}+2.86 \\
{[\text { Tracer2 }]_{\mathrm{ppb}}=} & 4.86 \times 10^{-3}\left[\mathrm{CH}_{4}\right]_{\mathrm{ppb}}-1.63 \times 10^{-2}\left[\mathrm{~N}_{2} \mathrm{O}\right]_{\mathrm{ppb}} \\
& +1.43 \times 10^{-3}[\mathrm{CFC}-113]_{\mathrm{ppt}}-1.52 \\
& \times 10^{-2}\left[\mathrm{CCl}_{3} \mathrm{~F}\right]_{\mathrm{ppt}}-0.175 \\
{[\text { Tracer3 }]_{\mathrm{ppb}}=} & 3.20 \times 10^{-4}\left[\mathrm{CH}_{4}\right]_{\mathrm{ppb}}-1.73 \times 10^{-3}\left[\mathrm{~N}_{2} \mathrm{O}\right]_{\mathrm{ppb}} \\
& -5.59 \times 10^{-3}\left[\mathrm{CCl}_{2} \mathrm{~F}_{2}\right]_{\mathrm{ppt}}+3.77 \\
{[\text { Tracer4 }]_{\mathrm{ppb}}=} & 2.22 \times 10^{-4}\left[\mathrm{CH}_{4}\right]_{\mathrm{ppb}}-5.03 \times 10^{-4}\left[\mathrm{~N}_{2} \mathrm{O}\right]_{\mathrm{ppb}} \\
& -3.91 \times 10^{-3}[\mathrm{OCS}]_{\mathrm{ppt}}-6.05 \\
& \times 10^{-3}\left[\mathrm{CCl}_{2} \mathrm{~F}_{2}\right]_{\mathrm{ppt}}+3.15 .
\end{aligned}
$$

Since Tracer 3 is not highly linearly correlated with ozone ( $R=0.9$, the other tracers have $R \geq 0.95$; see Tables $\mathrm{S} 1$ and S2 in the Supplement) and has a standard deviation of approximately $10 \%$ (see Fig. 3), this tracer has been eliminated from further analysis, as it seems unsuitable for determining the passive ozone accurately. Tracer 2 contains CFC113, which has limited coverage at higher altitudes due to a processing issue. As such, limited measurements are available to determine the passive ozone with this artificial tracer. 

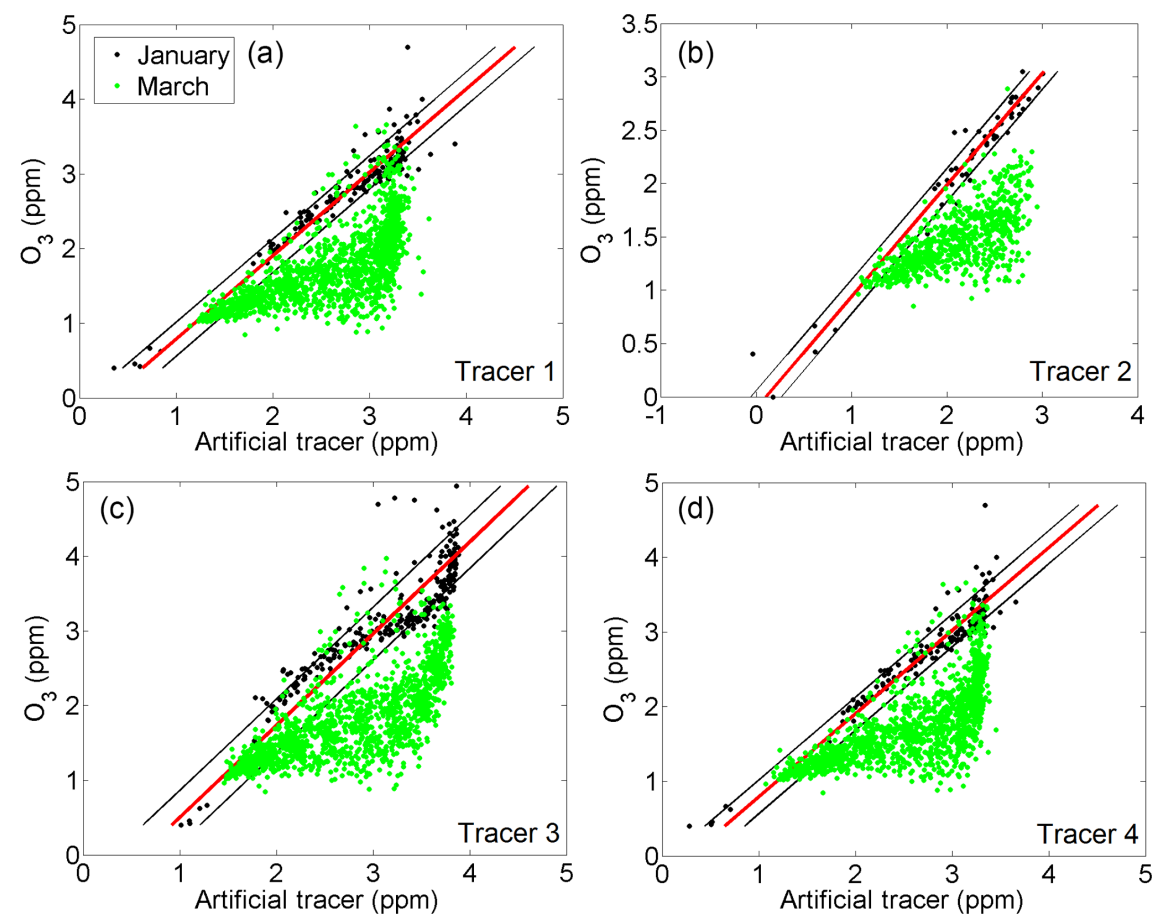

Figure 3. Artificial tracer correlation technique using ACE-FTS measurements inside the polar vortex in January (black dots) and March (green dots) 2011 using (a) Tracer 1, (b) Tracer 2, (c) Tracer 3, and (d) Tracer 4. The fitted correlations are shown as red lines, and the black lines indicate the $\pm 1 \sigma$ standard deviation of the fit. See text for further details on the artificial tracers.

Consequently, Tracer 2 is not a suitable tracer to use with the ACE-FTS v3.5 dataset. For further analysis only Tracer 1 and Tracer 4 were considered for determining the ozone depletion.

\subsection{Passive subtraction using CTMs}

In addition to approaches that only use the ACE-FTS dataset, the chemical ozone depletion was estimated by employing passive ozone from CTMs. The passive ozone from two different models, the Lagrangian ATLAS (Alfred Wegener Institute Lagrangian chemistry and transport system; Wohltmann and Rex, 2009; Wohltmann et al., 2010) and the Eulerian SLIMCAT (Chipperfield et al., 2006) models, has been used to investigate the chemical ozone depletion in March 2004-2013. Within these models, ozone can be treated as a passive tracer that is not influenced by chemical depletion processes, and only dynamics are applied to the modelled ozone concentrations. The passive subtraction methods using CTMs account for mixing of extra-polar vortex air; however, it is difficult to determine how well these mixing processes are represented within those models. Both models used in this study are driven by driven by the European Centre for Medium-range Weather Forecasts Reanalysis Interim (ECMWF ERA-Interim) meteorological reanalysis (Dee et al., 2011). In both models, ozone chemistry can be included by employing appropriate chemical reactions.

\subsubsection{Passive subtraction with ATLAS}

The ATLAS model was specifically developed to assess stratospheric chemistry, transport, and mixing. Passive ozone and the ozone that responds to both heterogeneous and homogeneous chemistry can be estimated with this model; however, in this study, only the passive ozone is used and compared to the ACE-FTS measurements to obtain the chemical ozone depletion. This model was previously used to estimate stratospheric ozone within the polar vortex (e.g. Adams et al., 2013; Wohltmann et al., 2013), and validation comparisons with measurements and other models have shown good agreement (Wohltmann and Rex, 2009; Wohltmann et al., 2010, 2013, 2017). For the model run presented in this study, the passive tracer was initialized each year on 1 January with Aura MLS (Waters et al., 2006) v3.3/3.4 ozone measurements. The ACE-FTS dataset cannot be used for this, since its daily latitude coverage is not sufficient for the initialization of the model. However, relative differences between Aura MLS and ACE-FTS ozone concentrations are small, between 2 and $5 \%$ in the stratosphere (Sheese et al., 2016). The passive ozone output has a horizontal resolution of $150 \mathrm{~km}$. The vertical coordinate is potential temperature $(\sim 350$ to $1900 \mathrm{~K})$. The vertical resolution of the model changes depending on altitude and is typically between 10 and $40 \mathrm{~K}$ at altitudes between 350 and $550 \mathrm{~K}$. Passive ozone concentrations are saved every $12 \mathrm{~h}$ at 00:00 and 12:00 UTC. 
Since ATLAS is a Lagrangian transport model, the locations of the model output change and are most likely not coincident with the location of the ACE-FTS measurements. To obtain the passive ozone concentration at the location of each $1 \mathrm{~km}$ tangent altitude for each ACE-FTS measurement, back or forward trajectories are utilized at individual altitudes to obtain the ACE-FTS measurement location or "end point" at the time of the ATLAS output. Since passive ozone amounts are obtained from ATLAS every $12 \mathrm{~h}$, the back or forward trajectories are estimated for a maximum of $6 \mathrm{~h}$. These forward and back trajectories were calculated with HYSPLIT (Hybrid Single-Particle Lagrangian Integrated Trajectory; Draxler and Hess, 2004), using the NCEP (National Centers for Environmental Prediction) reanalysis (Kalnay et al., 1996) for the meteorological input. Note that the time period of the back and forward trajectories is relatively short (a maximum of $6 \mathrm{~h}$ ); therefore differences in the meteorological input used to drive the CTM and those used for the trajectory calculations are small compared to the total uncertainty. The ATLAS data points that are at the same potential temperature levels (within ATLAS vertical resolution) as the end point of the ACE-FTS measurement are then triangulated. If the three closest ATLAS points that surround the end point of the trajectory are inside the polar vortex, they are interpolated to this position using a barycentric method. The interpolation is only done horizontally; we did not apply interpolation in the vertical direction but instead chose only ATLAS points that were at the same potential temperature levels as the ACE-FTS observations, within the resolution of ATLAS.

The passive ozone mixing ratios are compared to the ACEFTS measurements in January and March. The difference between the March measurements and the passive ozone is considered the chemical ozone loss. The difference between the ACE-FTS dataset and ATLAS for January is used to estimate an uncertainty of the modelled ozone. To determine the uncertainty of the model results, the relative differences between ACE-FTS measurements and the ATLAS passive ozone for January are calculated as [ACE-FTS-ATLAS] / $[0.5 \times($ ACE - FTS + ATLAS $)]$. These vary between 0.7 and $5.2 \%$, depending on the individual year. Note that these uncertainty estimates may include the effects of January ozone loss, which cannot be determined from these datasets. For the total uncertainty of the chemical ozone loss, the statistical fitting error from ACE-FTS v3.5 $\mathrm{O}_{3}$ measurements and the mean difference of ACE-FTS measurements and ATLAS passive ozone in January are added in quadrature. Note that the uncertainty estimated here is a lower bound on the actual uncertainty, since it does not consider the accumulated uncertainties in model transport since the initialization in January (e.g. caused by deficiencies in the ERA-Interim).

An example of the comparisons for January 2011 is shown in Fig. 4a. ATLAS passive and ACE-FTS measured ozone are in good agreement. The difference is, on average, $-5.2 \pm 0.7 \%$, with a high correlation coefficient $(R=0.94)$.
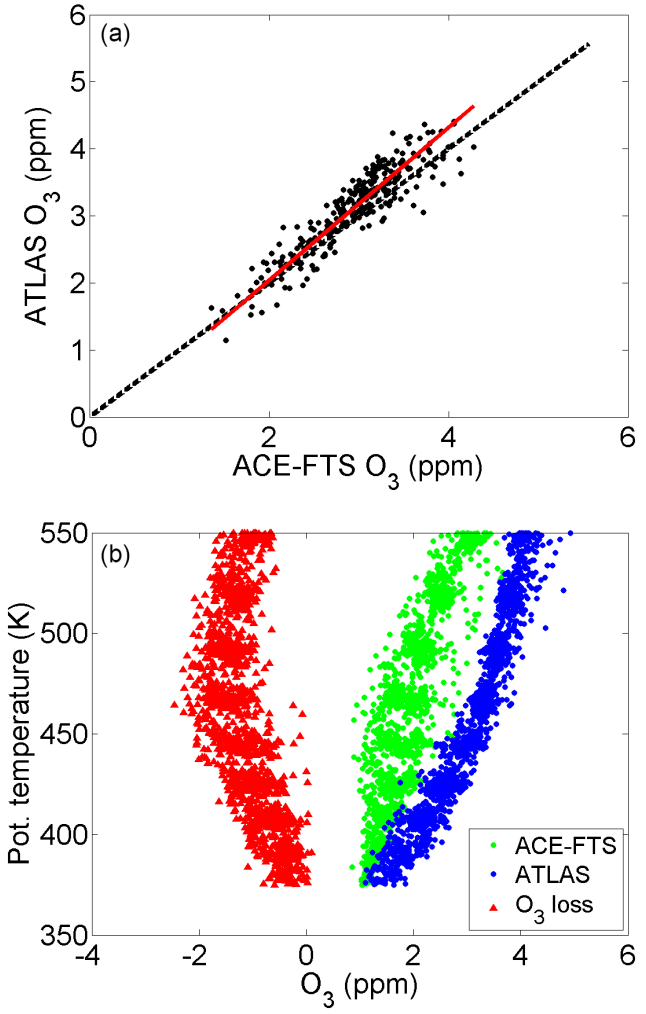

Figure 4. (a) shows a comparison between the ATLAS passive ozone and ACE-FTS ozone dataset inside the polar vortex for January 2011. The black dots represent the individual data points and the red line indicates the line of best fit. For easy comparison, the one-to-one line is shown as a black dashed line. (b) shows ATLAS passive $\mathrm{O}_{3}$ (blue dots), ACE-FTS measurements (green dots), and the ozone loss (red triangles; the difference between observed and average passive ozone) for March 2011

This difference between the ATLAS passive and ACE-FTS measured ozone is likely due to the difference between the Aura MLS and ACE-FTS datasets that is of the same order of magnitude. However, some of this difference could also be due to early ozone depletion in January, as was seen by Manney et al. (2015). The ACE-FTS measurements (green dots) and ATLAS passive ozone (blue dots) for March 2011 are displayed in Fig. 4b. The difference between the ATLAS and ACE-FTS ozone concentrations are displayed as red triangles and indicate chemical ozone loss.

\subsubsection{Passive subtraction with SLIMCAT}

In addition to ATLAS, we have also used the SLIMCAT offline 3-D CTM to investigate Arctic ozone loss. This model has been widely used to study the stratospheric ozone abundance and chemical ozone depletion (e.g. Feng et al., 2007; Sinnhuber et al., 2000; Singleton et al., 2005, 2007; Adams et al., 2012; Lindenmaier et al., 2012; Dhomse et al., 2013; Chipperfield et al., 2015). A detailed description of the model 
can be found in Chipperfield et al. (2006), and recent updates are described in Dhomse et al. (2013) and Chipperfield et al. (2015). SLIMCAT uses an Eulerian grid that extends from pole to pole. It contains a detailed stratospheric chemistry scheme including all processes that are related to polar ozone depletion (Chipperfield et al., 2006; Dhomse et al., 2013, and references therein). As such, passive ozone and ozone that responds to ozone chemistry are modelled. The model was also forced by ERA-Interim meteorological reanalysis (Dee et al., 2011). The passive ozone from the SLIMCAT model run was reset on 1 January for each year to the values of the model chemical ozone field at that time. The model simulation used here has a horizontal resolution of $2.8^{\circ} \times 2.8^{\circ}$, and the vertical coordinate is defined on hybrid $\sigma$-pressure vertical levels between the surface and approximately $60 \mathrm{~km}$ on 32 layers. The simulation was initialized in 1979 (using output from a 2-D model) and constrained by specified global mean surface observations of long-lived source gases. SLIMCAT therefore simulates ozone and all other stratospheric trace gases for all years in this study in a single long-term simulation. The model was sampled at the locations of the $30 \mathrm{~km}$ tangent altitude of the ACE-FTS occultations providing profiles of the passive ozone and ozone that responds to ozone chemistry corresponding to each measurement. Although the geolocations of the ACE-FTS measurements change with altitude, the location of the measurements at the altitudes of interest (approximately $15-25 \mathrm{~km}$ ) are within an approximately $0.5^{\circ}$ great circle of the location of the $30 \mathrm{~km}$ tangent altitude and are therefore within the model resolution. Therefore, the measurements and the modelled ozone fields can be directly compared without further processing. The ozone loss was estimated from the difference between the modelled passive ozone and the observed ozone inside the polar vortex in March. Additionally, the ozone loss has also been estimated by solely using both the modelled ozone that responds to ozone chemistry and the passive ozone from the model (referred to as "SLIMCAT only"). This helps to estimate the uncertainty of the modelled ozone (that includes ozone chemistry) by comparing it to the measurements and can indicate potential ozone loss in January by comparing the passive ozone and ozone (that includes ozone chemistry). To estimate the uncertainty of the model results, the relative differences between ACE-FTS measurements and the SLIMCAT ozone for January and March are calculated as [ACE-FTS - SLIMCAT] $/[0.5 \times($ ACEFTS + SLIMCAT)]. The ACE-FTS ozone measurements and the modelled ozone agree very well, with mean relative differences between 0.8 and $4.8 \%$ (and $R \approx 0.95$ ), depending on the specific year. The total uncertainty of the ozone loss was estimated in a similar way as was done for the ATLAS analysis (see Sect. 3.4.1); the ACE-FTS ozone measurement fitting error and the mean relative difference between ACEFTS and SLIMCAT ozone were added in quadrature. Note that the uncertainty estimated here is a lower bound on the actual uncertainty, since it does not consider the accumulated
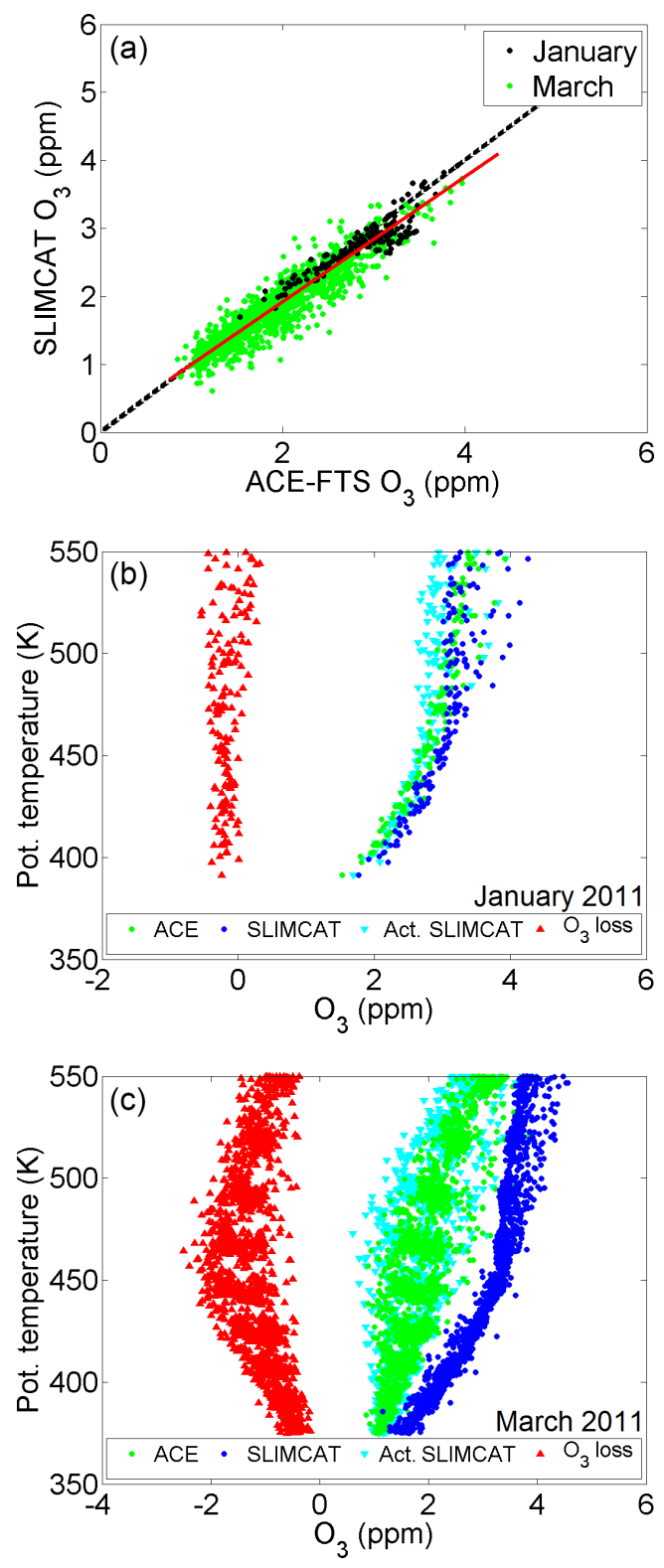

Figure 5. (a) shows a comparison between the SLIMCAT ozone and ACE-FTS ozone dataset inside the polar vortex for January (black dots) and March (green dots) 2011, with the combined regression fit for January and March shown as a red line. (b) and (c) show the comparison between the SLIMCAT ozone (passive ozone - SLIMCAT - shown as blue dots, and ozone with "active" chemistry - Act. SLIMCAT - as cyan triangles) and measurements (green dots) for January 2011 and March 2011, respectively. The ozone loss is displayed as red triangles and defined as the difference between the measurements and the modelled passive ozone.

uncertainties in model transport (e.g. caused by deficiencies in the ERA-Interim).

An example of the comparison for January and March 2011 is shown in Fig. 5a. The measurements and the model ozone are in good agreement with a mean difference of 


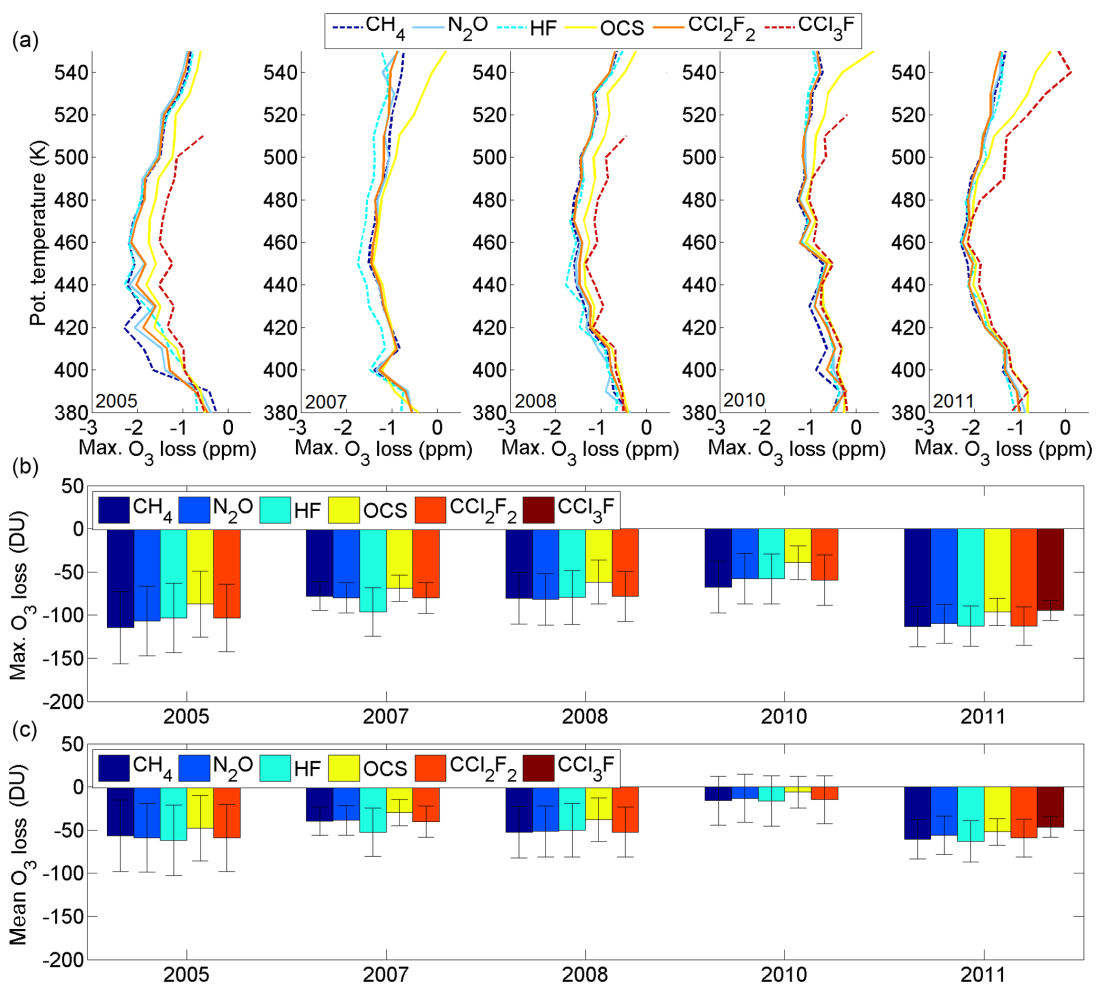

Figure 6. The ozone loss estimates are shown using the tracer-tracer correlation technique. Six different tracers have been employed for this method: $\mathrm{CH}_{4}$ (blue), $\mathrm{N}_{2} \mathrm{O}$ (light blue), $\mathrm{HF}$ (cyan), $\mathrm{OCS}$ (yellow), $\mathrm{CCl}_{2} \mathrm{~F}_{2}$ (orange), and $\mathrm{CCl}_{3} \mathrm{~F}$ (dark red). The maximum ozone loss profile (in ppmv) is shown in (a). For clarity, the uncertainties of the estimated ozone loss profiles have been removed. The integrated ozone loss (in DU) between 380-550 K is shown in (b) and (c) for the maximum and mean loss in March, respectively.

$3.9 \pm 0.8 \%$, and the correlation is high, with a correlation coefficient $R=0.95$. This result confirms that the model simulates the measured ozone quite well. In Fig. $5 b$ and c, ACEFTS measurements (green dots), SLIMCAT ozone (cyan triangles) and SLIMCAT passive ozone (blue dots) are displayed for January and March 2011, respectively. The ozone loss (red triangles) is obtained from the observed and modelled passive ozone, and indicates the chemical ozone loss. Figure $5 \mathrm{~b}$ confirms that little ozone depletion was observed in January 2011, as the differences between the measured and modelled passive ozone are on average around $0.1 \mathrm{ppmv}$. The results of the estimated ozone loss are discussed in Sect. 4.

\section{Annual intercomparison and interpretation of Arctic ozone loss estimates}

In this section, the impact of the different tracers and the different methods on the estimated ozone loss is discussed for the 5 years where no SSW event occurred. The mixing ratio profile and partial-column (380-550 K) ozone depletion are compared, and the differences are discussed.

\subsection{Impact of the choice of tracer}

For the tracer-tracer correlation method and the average vortex profile descent technique, six long-lived tracers $\left(\mathrm{CH}_{4}\right.$, $\mathrm{N}_{2} \mathrm{O}, \mathrm{HF}$, OCS, $\mathrm{CCl}_{3} \mathrm{~F}$, and $\mathrm{CCl}_{2} \mathrm{~F}_{2}$ ) have been used to estimate the chemical ozone depletion in the Arctic polar vortex in March with respect to January. These results are shown in Figs. 6 and 7, respectively. Two different combinations of tracers have been investigated to create an artificial tracer that is linearly correlated with ozone, and these results are displayed in Fig. 8. Panel (a) of Figs. 6-8 shows the mixing ratio loss profile of the maximum chemical ozone loss between 380 and 550 K in March 2005, 2007, 2008, 2010, and 2011. The partial-column ozone loss presented here is estimated from the mixing ratio losses using the mean altitudes of the DMP's potential temperature profile, between $380 \mathrm{~K}$ and $550 \mathrm{~K}$, and the ACE-FTS densities at the given altitude level. This interpolation to altitude levels was necessary for the estimation of the integrated partial columns (Nathaniel Livesey, personal communication, 2016). Panels (b) and (c) of Figs. 6-8 show the maximum and mean partialcolumn ozone loss, respectively. The error bars displayed in panels (b) and (c) of Figs. 6-8 indicate the uncertainty of the maximum and mean column ozone loss estimates that are 


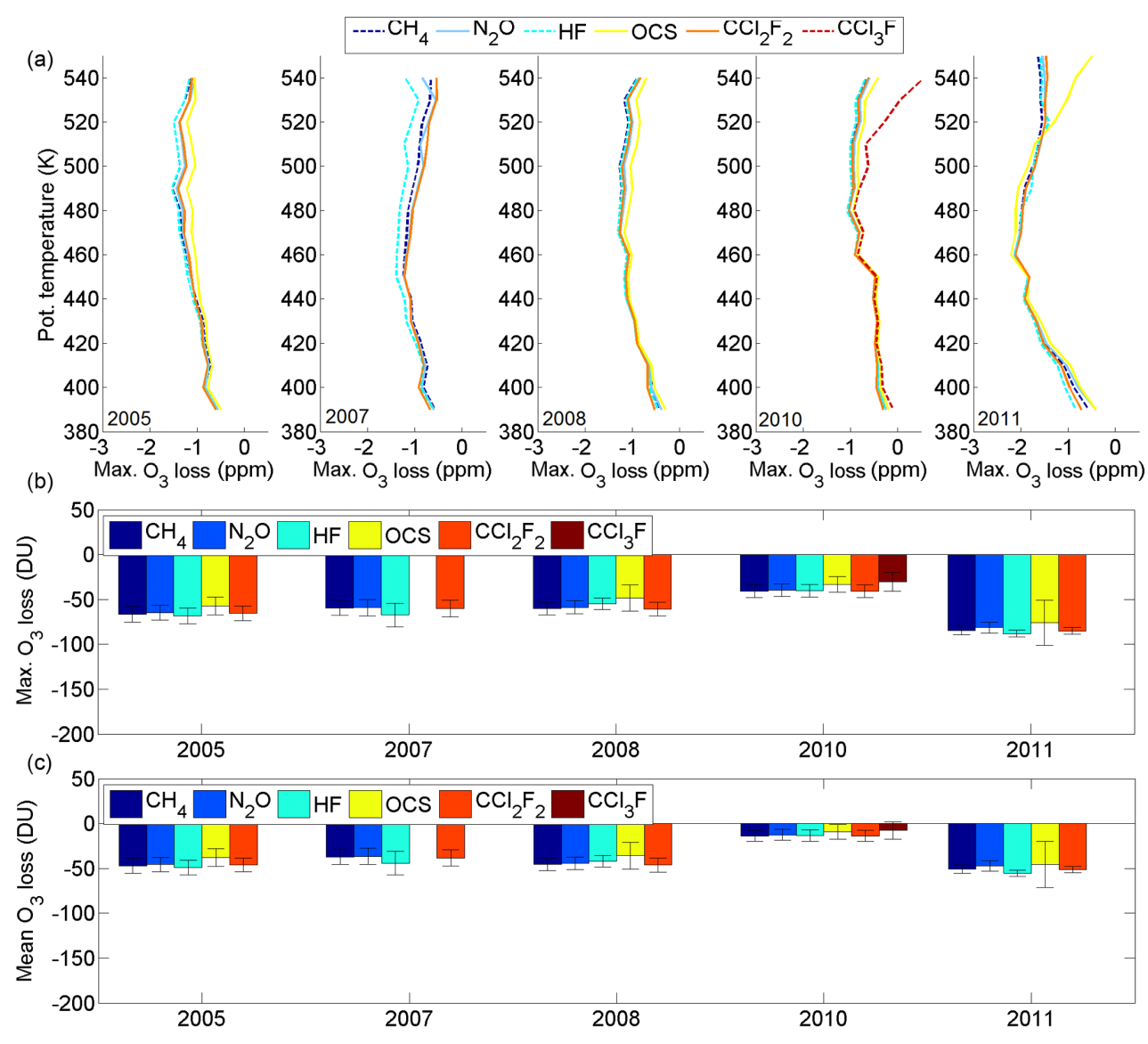

Figure 7. Same as Fig. 6, but for the average vortex profile descent technique.

derived from maximum and mean ozone loss VMR uncertainties, respectively, as calculated in Sect. 3.

For the tracer-tracer correlation method (Fig. 6), the results for all six tracers are similar for the partial-column ozone. However, there are differences apparent in the profile of the estimated ozone loss for each tracer, especially for high and low altitudes. The estimated uncertainties of the ozone loss profile are $\sim 0.2-0.6$ ppmv, or approximately $\sim 10-20 \%$ of the estimated ozone loss, and the results from all tracers agree within the uncertainties between approximately 460 $500 \mathrm{~K}$ for all years, with the exception of 2005. Both mixing and strong ozone loss was apparent in the winter of 20042005 (e.g. Manney et al., 2006) and is consequently a good year to test the agreement between the different tracers. As shown in Fig. 6a, the profiles of the different tracers do not agree well in March 2005. This indicates the shortcomings of the tracer-tracer correlation method, even in cases where only inner core vortex measurements were used for estimating the ozone loss. These results are consistent with previous studies (e.g. Michelsen et al., 1998; Plumb et al., 2000, 2003; Plumb, 2007) that have shown that tracer-tracer correlations are not expected to be accurate for estimating Arctic ozone loss. However, in this study, though the profile loss es- timates are different for different tracers, the partial-column losses (maximum and mean) are not significantly different and agree within the estimated uncertainties.

Both OCS and $\mathrm{CCl}_{3} \mathrm{~F}$ results show a smaller ozone loss $(\sim 0.5-1 \mathrm{ppmv})$ above approximately $500 \mathrm{~K}$ compared to the other tracers in all years. For most years, the ozone loss profiles computed with $\mathrm{CH}_{4}, \mathrm{~N}_{2} \mathrm{O}, \mathrm{HF}$, and $\mathrm{CCl}_{2} \mathrm{~F}_{2}$ agree well and within the estimated uncertainties for the entire profile. The largest discrepancies between the tracers occur in 2005, when the vortex was relatively weak and influenced by mixing. Also, in 2007, the estimated loss is larger when HF is used as a tracer, and it does not follow the ozone loss profile as estimated with other tracers. For the partial-column losses, all tracers agree within the estimated uncertainties. However, these uncertainties are quite large, between approximately 20 and $40 \mathrm{DU}$, and represent roughly $40-60 \%$ of the estimated ozone loss. The estimated profile and partial-column ozone loss is consistently smaller ( $\sim 10 \mathrm{DU})$ if $\mathrm{OCS}$ or $\mathrm{CCl}_{3} \mathrm{~F}$ is used as the tracer. In the ACE-FTS v3.5 dataset many $\mathrm{CCl}_{3} \mathrm{~F}$ retrievals fail, especially in higher altitudes. Typically only one quarter to half as many profiles are available each year compared to the other tracers. Due to this limited coverage, the column ozone loss could only be estimated with $\mathrm{CCl}_{3} \mathrm{~F}$ in 

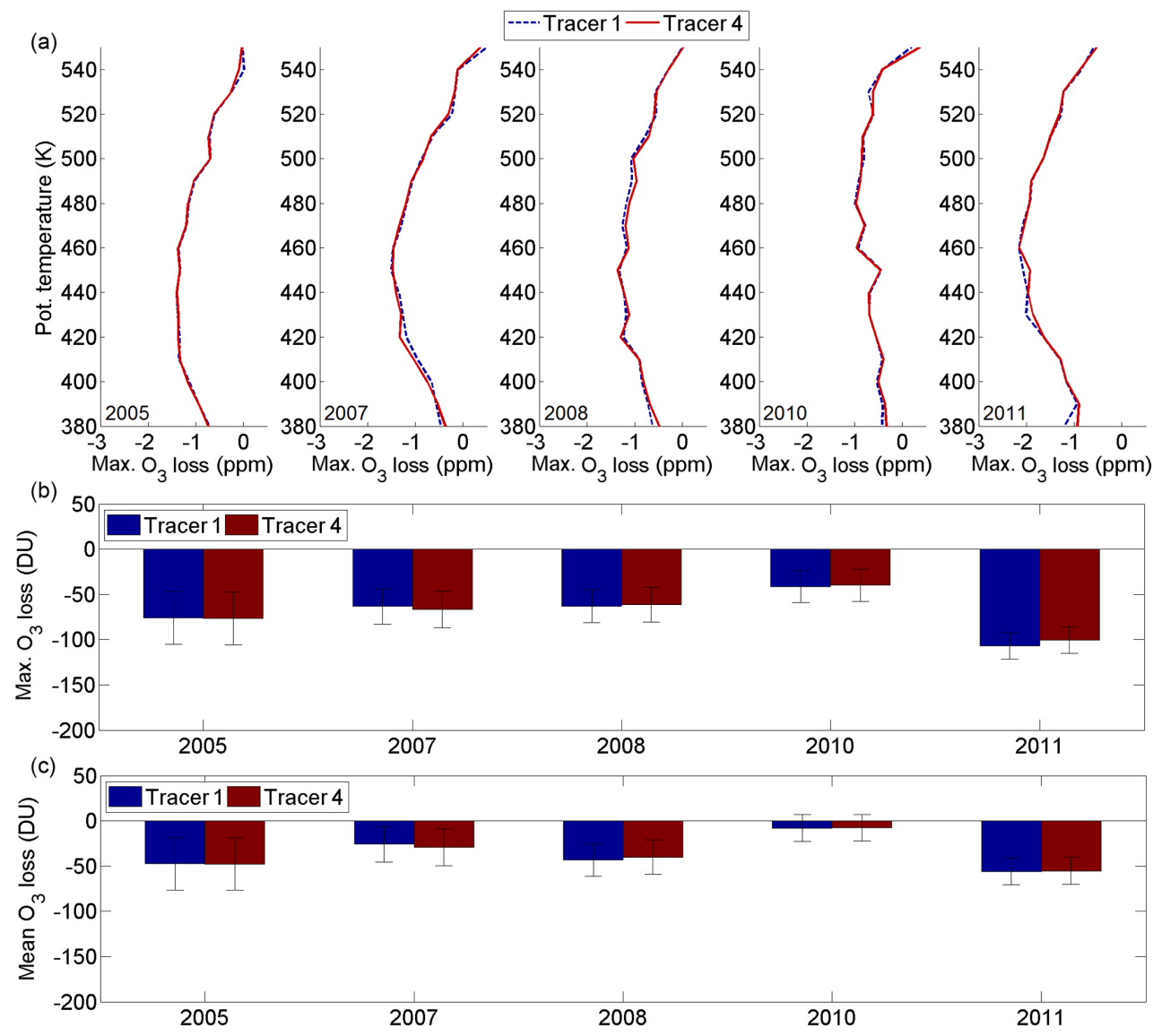

Figure 8. Similar to Fig. 6, but for the artificial tracer correlation method. Tracer $1\left(\mathrm{~N}_{2} \mathrm{O}, \mathrm{CH}_{4}, \mathrm{CCl}_{2} \mathrm{~F}_{2}\right.$, and $\left.\mathrm{CCl}_{3} \mathrm{~F}\right)$ in dark blue and Tracer $4\left(\mathrm{~N}_{2} \mathrm{O}, \mathrm{CH}_{4}, \mathrm{OCS}\right.$, and $\left.\mathrm{CCl}_{3} \mathrm{~F}\right)$ in dark red. Details about the composition of the four tracers are provided in the text.

2011. It should be noted that OCS has a significantly shorter stratospheric lifetime that is approximately 2 years (Montzka et al., 2007; Dhomse et al., 2014), whereas all other tracers have lifetimes of over 50 years (Hoffmann et al., 2014; Brown et al., 2013). As OCS is not as stable as all other tracers, this could negatively impact the ozone loss estimation using OCS.

Using these six different tracers to estimate the average vortex descent rate (Fig. 7) leads to very similar results for most tracers, except for OCS. The uncertainties for this method are $\sim 0.02-0.1 \mathrm{ppmv}$, or $\sim 1-10 \%$. These are smaller than the ones estimated for the tracer-tracer method due to the small standard deviation of the average vortex descent profile. Note that this does not represent the true uncertainty and represents a statistical uncertainty. The true uncertainty is likely much higher, since only one passive ozone profile for each March is applied (and, therefore, the same amount of ozone at each potential temperature level). The profile loss estimated for these different tracers looks similar for most years, with the exemption of OCS in 2005, 2008, and 2011, and $\mathrm{CCl}_{3} \mathrm{~F}$ in 2010 . During the winters of 2004-2005, 20062007, and 2009-2010, when using OCS, an ascent inside the polar vortex rather than descent is estimated (for all calculated descent rates, see Tables S3-S8 in the Supplement). In 2007-2008 and 2010-2011, when $\mathrm{CH}_{4}, \mathrm{~N}_{2} \mathrm{O}, \mathrm{HF}$, and $\mathrm{CCl}_{2} \mathrm{~F}_{2}$ estimate a large descent of approximately $20-35 \mathrm{~K}$ over 1.5 months (between approximately $450-550 \mathrm{~K}$; see Tables S3-S8 in the Supplement), OCS only estimates half as much. The reason for this could be the limited precision of the ACE-FTS OCS retrievals that have retrieval fitting errors of around $10 \%$, almost 10 times higher than for other species (e.g. $\mathrm{O}_{3}$ and $\mathrm{N}_{2} \mathrm{O}$ ). As shown in Fig. 7 a, the mixing ratio loss profile is very similar with all different tracers, with the exception of HF in 2007, where a larger chemical ozone depletion is estimated. This large discrepancy is also seen in 2007 for the tracer-tracer correlation method. For this winter, the descent rates using HF are almost twice as large as those derived from the other tracers; for all other years HF provides descent rates that are similar to the other tracers. Due to the large estimated uncertainties of the integrated loss ( 2.4-6.5 DU), the estimated partial-column ozone loss for each year agrees for all different tracers within the estimated uncertainties. Only in 2010 could the partial-column ozone depletion (between $380-550 \mathrm{~K}$ ) be estimated using $\mathrm{CCl}_{3} \mathrm{~F}$ 


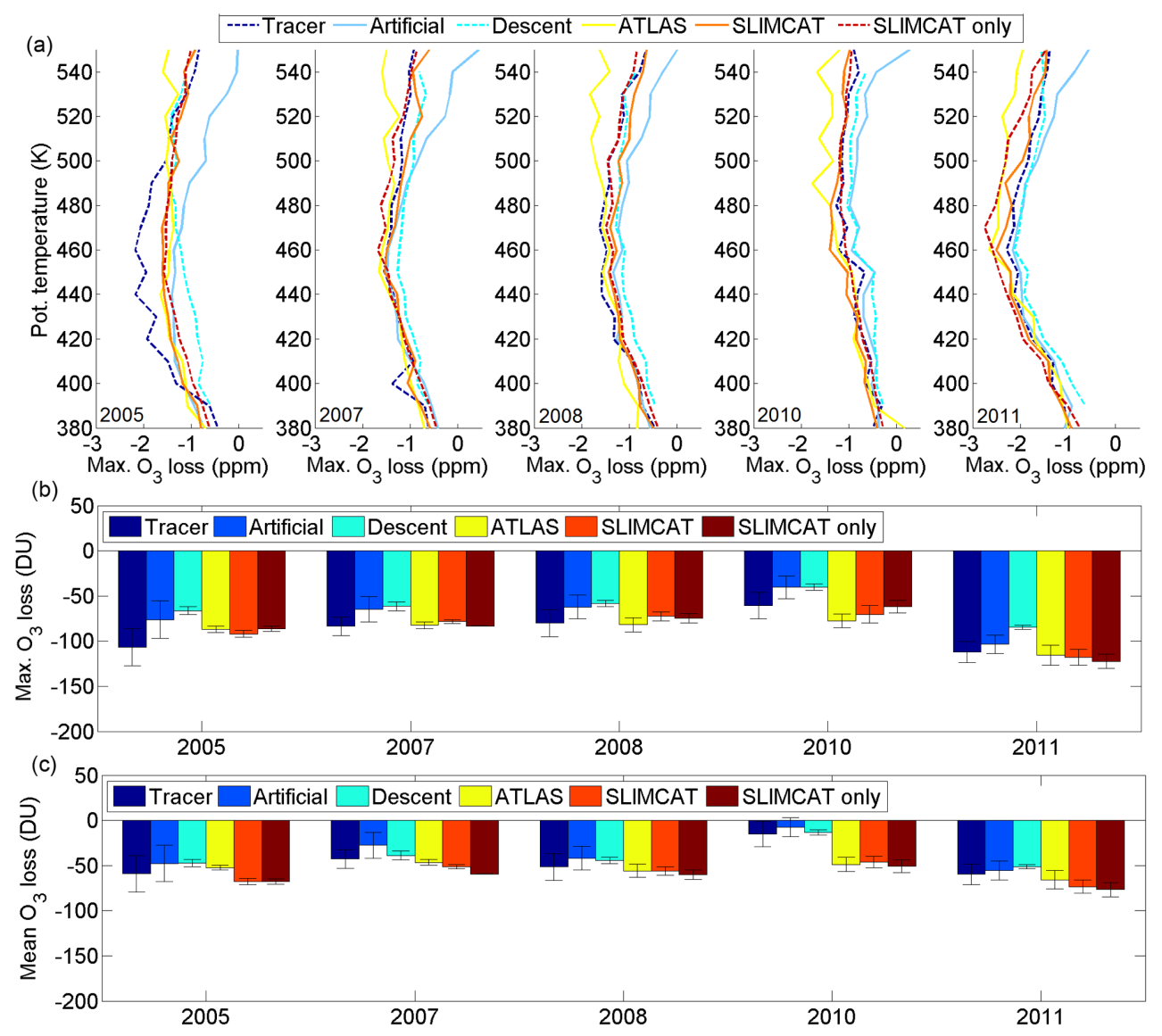

Figure 9. Same as Fig. 6, but for the comparison of all different methods: tracer-tracer correlation (blue), artificial tracer correlation (light blue), average vortex profile descent technique (cyan), passive subtraction with ATLAS (yellow), passive subtraction with SLIMCAT (orange), and passive subtraction using only modelled ozone from SLIMCAT (dark red). An average using different tracers is used for the tracer-tracer correlation, the artificial tracer correlation, and the average vortex profile descent technique; see text for details.

because of limited retrievals for this species. Because ACEFTS fitting errors of OCS are quite large and there are limited ACE-FTS $\mathrm{CCl}_{3} \mathrm{~F}$ retrievals, it is not advised to use OCS or $\mathrm{CCl}_{3} \mathrm{~F}$ with the ACE-FTS v3.5 dataset to determine the average vortex profile descent rates and subsequent ozone loss.

Two different combinations of tracers have been used to create artificial tracers that are used to estimate ozone losses (Fig. 8). The ozone loss profiles and partial-column ozone losses computed from Tracer 1 and Tracer 4 are very similar, with differences of typically less than $0.1 \mathrm{pmv}$ (the uncertainty of these calculated ozone loss profiles is $0.2-0.3 \mathrm{ppmv}$ at all altitudes). As expected based on the profile ozone loss, the estimated column ozone losses shown in Figs. 8b and c agree within approximately 5 DU for Tracer 1 and Tracer 4 . The uncertainties of the column ozone loss for these artificial tracers are typically between 15 and $30 \mathrm{DU}$ (this equals roughly $30-50 \%$ of the estimated loss depending on the year).

To summarize, for the tracer-tracer correlation, average vortex profile descent, and artificial tracer correlation ap- proaches, the computed partial-column ozone losses for most tracers agree within the estimated uncertainties (which can vary between approximately 2.5 and $40 \mathrm{DU}$, depending on the method and year). The results for the profile and partialcolumn losses are most consistent when using $\mathrm{CH}_{4}, \mathrm{~N}_{2} \mathrm{O}$, $\mathrm{HF}$, and $\mathrm{CCl}_{2} \mathrm{~F}_{2}$ for the tracer-tracer correlation and profile descent techniques. However, using OCS or $\mathrm{CCl}_{3} \mathrm{~F}$ as a tracer, at least for the ACE-FTS v3.5 dataset, seems to result in larger uncertainties and has the disadvantage that there are not as many profiles available as there are for the rest of the tracers. Based on this analysis with the ACE-FTS v3.5 dataset, the best choices of tracers are $\mathrm{CH}_{4}, \mathrm{~N}_{2} \mathrm{O}, \mathrm{HF}$, and $\mathrm{CCl}_{2} \mathrm{~F}_{2}$. For the artificial tracer method, Tracer 1 and Tracer 4 seem to be equally suited for ACE-FTS v3.5.

To be able to compare between the different methods using the tracer-tracer correlation, the artificial correlation, and the average profile descent techniques in the following section, average mixing ratios and integrated ozone losses have been calculated as follows. The average mixing ratio loss using $\mathrm{CH}_{4}, \mathrm{~N}_{2} \mathrm{O}$, $\mathrm{HF}$, and $\mathrm{CCl}_{2} \mathrm{~F}_{2}$ is utilized for the tracer- 
tracer correlation and average vortex profile descent methods. For the artificial tracer method, the average of Tracer 1 and Tracer 4 is employed. The uncertainties of these averages have been computed by propagating the uncertainties from each method and tracer. Note that the higher losses using HF as a tracer in 2007 increase the partial column and the profile ozone loss by approximately $7 \%(\sim 3 \mathrm{DU}$ and $\sim 0.05 \mathrm{ppmv}$, respectively).

\subsection{Comparison between the different methods}

The mixing ratio and partial-column ozone losses have been derived for March 2005, 2007, 2008, 2010, and 2011 using six different methods, as described above, and are shown in Fig. 9. As expected, all of these methods consistently show the greatest chemical ozone loss in March 2011 (e.g. Manney et al., 2011; WMO, 2014; Livesey et al., 2015). The second largest ozone depletion event for these years occurred in 2005. Based on our results, the losses in 2007 and 2008 seem to be similar and are only slightly smaller than those in 2005 . In 2010, the mean partial-column ozone depletion seems to be lower than for the other years. This can be explained by mixing and the break up of the polar vortex during this winter (e.g. Dörnbrack et al., 2012; Kuttippurath and Nikulin, 2012; Wohltmann et al., 2013). These estimated losses are as expected and are consistent with previous studies (WMO, 2011, 2014; Livesey et al., 2015).

The maximum mixing ratio loss profiles, as displayed in Fig. 9a, show reasonably good agreement between the different methods. The maximum ozone losses computed at $460 \mathrm{~K}$ (the approximate height of the peak ozone loss) are 1.2$1.6 \mathrm{ppmv}$ (mean: $1.5 \mathrm{ppmv}$ ) in 2005 (excluding the tracertracer method that showed a peak loss of 1.9-2.5 ppmv), 1.2$1.8 \mathrm{ppmv}$ (mean: $1.5 \mathrm{ppmv}$ ) in 2007, 1.1-1.4 ppmv (mean: $1.3 \mathrm{ppmv}$ ) in 2008, 0.9-1.3 ppmv (mean: $1.1 \mathrm{ppmv}$ ) in 2010, and 2.1-2.7 ppmv (mean: $2.3 \mathrm{ppmv}$ ) in 2011. The uncertainties of these losses are on the order of $5-10 \%$ for all methods, except for the average vortex profile descent technique that is around $\pm 1.5 \%$. There is significantly larger estimated ozone loss in 2005 when using the tracer-tracer correlation method. The estimated peak ozone loss at $460 \mathrm{~K}$ is $2.2 \pm 0.3 \mathrm{ppmv}$, whereas the other methods estimate the loss between $1.2 \pm 0.1$ and $1.6 \pm 0.1 \mathrm{ppmv}$. The maximum partial-column ozone loss using the tracer-tracer technique is $107 \pm 20$ DU, whereas the other methods show smaller losses that are between 66 and 92 DU (see Fig. 9 and Table 1). A comparable partial-column loss (120 DU) to our loss estimate using the tracer-tracer correlation method has been estimated by Tilmes et al. (2006), with satellite-borne HALOE observations using the tracer-tracer correlation method. The peak ozone loss in 2005 has also been estimated by Rösevall et al. (2008) using the tracer-tracer correlation technique (with the satellite-borne MLS and Sub-Millimetre Radiometer - SMR - instruments) that is around $1 \mathrm{ppmv}$ and more comparable with our other loss estimates.
As previously discussed, the Arctic stratosphere in 2005 was affected by strong ozone loss and mixing (WMO, 2006) and is consequently an ideal year to test whether the different methods agree and whether the models are accurate (Livesey et al., 2015). In some years, the tracer-tracer correlation method and the average vortex descent technique differ significantly from all other estimation methods. These differences highlight the difficulty of using the tracer-tracer correlation method, because mixing processes and the descent in the 2005 Arctic vortex are not accounted for. These differences also highlight the difficulty of using the average vortex descent technique in years of an unstable polar vortex. The average polar vortex descent technique typically underestimates the ozone loss compared to all other methods, this technique only agrees well with the other methods in March 2007 and 2008.

The mean and maximum partial-column ozone losses are summarized in Table 1 and are displayed in Figs. 9b and c, respectively. The uncertainties from the tracer-tracer correlation and artificial tracer methods are large in all years compared to all other methods. These are on the order of 10 $20 \mathrm{DU}$ and are based on the $\pm 1 \sigma$ standard deviation of the early vortex reference function (see Sect. 3.1 and 3.3). Much smaller uncertainties (2-10 DU) have been determined for calculations using the model output, which are based on the mean differences between the measurements and model output. For ATLAS, this is based on the difference between the model passive ozone and measurements in January each year. In contrast, the ozone loss uncertainty computed with SLIMCAT is based on the difference between the model ozone and measurements in both March and January and is very similar to the estimated ATLAS uncertainties. The maximum ozone loss in March combining all methods (see Fig. 9b and Table 1) was estimated to be $86 \mathrm{DU}$ in $2005,76 \mathrm{DU}$ in 2007 , $72 \mathrm{DU}$ in 2008, $59 \mathrm{DU}$ in 2010, and 109 DU in 2011. The March mean ozone loss (Fig. 9c and Table 1) obtained from these methods is 57, 44, 52, 30, and 66 DU for 2005, 2007, 2008, 2010, and 2011, respectively.

Discrepancies are apparent between the measurementonly methods and the passive subtraction using CTMs for 2010, especially for the computed mean partial-column loss. Each time the vortex splits and the two parts reunite, extravortex air is mixed. In 2010 the polar vortex was very disturbed; therefore, methods that do not account for the mixing of extra-vortex air (the tracer-tracer method, the profile descent technique, and the artificial tracer technique) are not reliable for that year, since an isolated vortex is essential for these methods. The loss estimates in 2010 using the measurement-only techniques do not agree with the passive subtraction using CTMs. Generally, we see the largest differences between the passive subtraction method using CTMs and methods that use only measurements for years with strong turbulence and relatively small ozone loss (see Table 1). For example in 2010, the passive subtraction methods using CTMs are nearly twice as high for the maximum 
Table 1. Maximum and mean partial-column ozone loss estimate (in DU) between $380-550 \mathrm{~K}$ from various methods (see details in the text), for March 2005, 2007, 2008, 2010, and 2011. The $\pm 1 \sigma$ uncertainties are stated, and the derivation is described in the text. These results are compared to previous quantifications of the integrated ozone loss (3500-550 K) between 1 January and 1 April using the Aura MLS dataset by Livesey et al. (2015) and Kuttippurath et al. (2010, 2012).

\begin{tabular}{lrrrrr}
\hline partial-column losses & 2005 & 2007 & 2008 & 2010 & 2011 \\
\hline Tracer-tracer (max.) & $107 \pm 20$ & $84 \pm 10$ & $80 \pm 15$ & $61 \pm 15$ & $112 \pm 11$ \\
Artificial tracer (max.) & $76 \pm 21$ & $65 \pm 14$ & $62 \pm 13$ & $41 \pm 13$ & $103 \pm 10$ \\
Descent (max.) & $66 \pm 4$ & $61 \pm 5$ & $59 \pm 4$ & $41 \pm 4$ & $85 \pm 2$ \\
ATLAS (max.) & $87 \pm 3$ & $83 \pm 4$ & $82 \pm 8$ & $78 \pm 8$ & $116 \pm 11$ \\
SLIMCAT (max.) & $92 \pm 4$ & $78 \pm 2$ & $73 \pm 5$ & $70 \pm 10$ & $115 \pm 9$ \\
SLIMCAT only (max.) & $86 \pm 3$ & $83 \pm 1$ & $75 \pm 5$ & $62 \pm 7$ & $122 \pm 8$ \\
Average for all (max.) & 86 & 76 & 72 & 59 & 109 \\
\hline Tracer-tracer (mean) & $59 \pm 20$ & $43 \pm 10$ & $52 \pm 15$ & $15 \pm 14$ & $60 \pm 11$ \\
Artificial tracer (mean) & $47 \pm 20$ & $28 \pm 14$ & $44 \pm 13$ & $8 \pm 10$ & $56 \pm 10$ \\
Descent (mean) & $47 \pm 4$ & $39 \pm 5$ & $45 \pm 4$ & $13 \pm 3$ & $61 \pm 2$ \\
ATLAS (mean) & $52 \pm 3$ & $46 \pm 3$ & $56 \pm 7$ & $49 \pm 8$ & $66 \pm 10$ \\
SLIMCAT (mean) & $67 \pm 3$ & $51 \pm 2$ & $56 \pm 5$ & $46 \pm 6$ & $73 \pm 7$ \\
SLIMCAT only (mean) & $67 \pm 3$ & $59 \pm 1$ & $60 \pm 5$ & $51 \pm 7$ & $77 \pm 8$ \\
Average for all (mean) & 57 & 44 & 52 & 30 & 66 \\
\hline Livesey et al. (max.* ${ }^{*}$ & 88 & 54 & 66 & 44 & 117 \\
Kuttippurath et al. (max. ${ }^{*}$ ) & 81 & 62 & 90 & 42 & 115 \\
\hline
\end{tabular}

* Integrated loss between 1 January and 1 April; this is approximately equivalent to the maximum losses reported in this study.

ozone loss and are more than three times as high for the mean ozone loss than the methods that use measurements only. This could either be due to mixing processes unaccounted for in the methods using measurements only, or the passive subtraction methods using CTMs may overestimate passive ozone.

The maximum ozone loss computed from the average vortex profile descent technique is low compared to the other methods; however, the mean losses agree. This discrepancy is likely because the average profile descent technique only provides a mean passive ozone profile. Hence, this method is capable of estimating an average across the vortex but not a specific maximum loss. Using modelled passive ozone to determine the mean loss leads to larger ozone loss than for the methods that are using measurements only. This may be in part because the models are initialized on 1 January each year, whereas ACE-FTS measurements start at the end of January. However, based on the difference between the modelled passive ozone (from ATLAS and SLIMCAT) and the measured ozone in January, this can only account for a difference of up to $6 \%$.

Using the passive subtraction method with a Lagrangian (ATLAS) or an Eulerian (SLIMCAT) model leads to very similar computed ozone losses. For the maximum partial-column ozone loss, the results from both models agree to differences within the estimated uncertainties for all years. These differences are between 1 and 9DU (between 2 and $12 \%$ ), where the smallest difference occurs in 2011 and the largest in 2008. The mean partial-column ozone losses agree within 1-15 DU and are within the estimated uncertainties for most years (except in 2005). The ozone loss has also been estimated using only the SLIMCAT modelled ozone ("SLIMCAT only"). The mean loss results for using the SLIMCAT passive ozone and ACE-FTS measurements are very similar to the mean losses computed from SLIMCAT only and differ between 0.3-8.0 DU (0.5$14 \%$ ); the largest difference was found in 2007. The maximum losses are also similar between these two estimation methods. These differences are between 2 and $8 \mathrm{DU}$, and the largest difference ( $8 \mathrm{DU}, \sim 13 \%$ ) was found in 2010, a year when the polar vortex was highly influenced by mixing, which is still within the estimated uncertainties.

Other studies have used the Aura MLS dataset to derive ozone depletion over this time period. Between 1 January and 1 April, for the years studied, Livesey et al. (2015) found losses of 1 ppmv at $450 \mathrm{~K}$ in 2005, 2007, and 2008 and of around 2 ppmv in 2011 using a Match-based approach that uses trajectory calculations to identify the same air parcel measured at various times (von der Gathen et al., 1995; Rex et al., 1998). During the same time period, Kuttippurath et al. (2010) and Kuttippurath et al. (2012), who used a passive subtraction approach with CTMs, found peak losses at approximately $450-475 \mathrm{~K}$ of $1.5 \mathrm{ppmv}$ in $2005,1.2 \mathrm{ppmv}$ in 2007, $1.4 \mathrm{ppmv}$ in 2008, $0.9 \mathrm{ppmv}$ in 2010, and $2.4 \mathrm{ppmv}$ in 2011. The mixing ratio losses estimated (excluding the previously discussed outlier, the tracer-tracer correlation method in 2005) in this study agree well with Livesey et al. (2015) and Kuttippurath et al. (2010, 2012). Here, we found similar 
Table 2. Estimates of the peak altitude and maximum ozone loss observed during the 2010-2011 Arctic winter.

\begin{tabular}{llrr}
\hline Study & Method/Instrument & Peak altitude (K) & Loss (ppmv) \\
\hline This work & Tracer-tracer/ACE-FTS & 460 & $2.28 \pm 0.15$ \\
This work & Artificial tracer/ACE-FTS & 460 & $2.16 \pm 0.14$ \\
This work & Descent/ACE-FTS & 460 & $2.13 \pm 0.03$ \\
This work & Passive subtraction (ATLAS)/ACE-FTS & 460 & $2.46 \pm 0.18$ \\
This work & Passive subtraction (SLIMCAT)/ACE-FTS & 460 & $2.50 \pm 0.12$ \\
This work & Passive subtraction (SLIMCAT only) & 460 & $2.57 \pm 0.12$ \\
This work & Average for all & 460 & 2.34 \\
\hline Livesey et al. (2015) & Match/Aura MLS & 450 & $2.0 \pm 0.3$ \\
Kuttippurath et al. (2012) & Passive subtraction/Aura MLS & 475 & $\sim 2.4$ \\
Manney et al. (2011) & Aura MLS, O3 sonde & 450 & $2.3-2.5$ \\
Sinnhuber et al. (2011) & Passive subtraction/MIPAS & $450-475$ & $2.3-2.5$ \\
von Hobe et al. (2013) & Match/O 3 sonde & 460 & $2.6 \pm 0.5$ \\
\hline
\end{tabular}

losses at around $460 \mathrm{~K}, 1.2-2 \mathrm{ppmv}$ in $2005,1.0-1.5 \mathrm{ppmv}$ in 2007, 1.2-1.6 ppmv in 2008, 0.8-1.3 ppmv in 2010, and 2.0$2.7 \mathrm{ppmv}$ in 2011. A comparison of the partial-column ozone loss with these two studies is shown in Table 1. It should be noted that the time period used by Livesey et al. (2015) and Kuttippurath et al. (2010, 2012) is slightly longer (1 January to 1 April), including the loss throughout January, and the altitude range is slightly larger; hence, the loss is expected to be larger than the estimated mean ozone loss columns here. Although Livesey et al. (2015) and Kuttippurath et al. (2010, 2012) have reported the total ozone loss by the beginning of April, our estimated mixing ratio and the partial-column ozone losses are consistent with these two studies for all the years. This suggests that not only are the computed losses consistent when using the ACE-FTS dataset with different methods, but similar ozone losses are also computed when the MLS dataset is employed instead. The following section will further discuss the ozone depletion in 2011 as a case study.

Overall, we have found that the different methods agree in most years within the estimated uncertainties considering the profile mixing ratio loss as well as the mean and maximum partial-column ozone loss. Typically, the average vortex profile descent method estimates smaller ozone losses compared to all other methods. This method provides an approximate ozone loss estimate, however, from only one passive ozone profile; hence, the passive ozone is the same throughout the month at each potential temperature level. The tracer-tracer correlation and the artificial tracer approaches have estimated uncertainties that are approximately twice as large compared to the passive subtraction using CTMs and the average vortex profile descent techniques. This is due to the large uncertainties for the early vortex reference function used for the tracer methods. Furthermore, consistent results were found using the passive subtraction method with both a Lagrangian and an Eulerian model. For the presented years, the ACE-FTS measurements and the SLIMCAT ozone (that includes ozone chemistry) results are in very good agreement with mean differences of less than $5 \%$ in January and March. As such, similar ozone losses are computed when SLIMCAT and no measurements are utilized.

\subsection{Comparison to previous estimates of the 2011 Arctic ozone loss}

Since the ozone loss in the Arctic during the 2010-2011 winter was extreme, this particular winter has been widely studied. Therefore, a more comprehensive comparison is available for this specific winter. Table 2 shows the estimated peak chemical ozone depletion and the altitudes at which these losses occurred from these studies. In these previous studies, the passive subtraction using CTMs and the Match approaches have been used to determine the Arctic chemical ozone depletion in 2010-2011. Several different instruments, such as Aura MLS, MIPAS, and ozonesondes, have been employed in these estimates.

The various methods that have been utilized in the current study consistently show the peak of the ozone loss at $460 \mathrm{~K}$. This is in very good agreement with the all of the previous results in Table 2, where the altitude of the peak ozone loss was determined between 450 and $475 \mathrm{~K}$. The maximum loss simulated in this study at $460 \mathrm{~K}$ is between 2.1 and $2.7 \mathrm{ppmv}$, which agrees well with Sinnhuber et al. (2011), Manney et al. (2011), Kuttippurath et al. (2012), von Hobe et al. (2013), and Livesey et al. (2015); see Table 2. The smallest ozone loss in any of the studies, approximately $2.0 \mathrm{ppmv}$, was found by Livesey et al. (2015); when their calculations were updated using Modern-Era Retrospective analysis for Research and Applications, Version 2 (MERRA-2) for the trajectory calculations, ozone loss estimates were more in line with those in the other studies (Nathaniel Livesey, personal communication, 2016). Of the six methods we used, it was found that the smallest losses are computed for the average vortex profile descent technique from this study. The passive subtraction method using CTMs has also been used in 2011, 
e.g. Sinnhuber et al. (2011) and Kuttippurath et al. (2012), with different models and datasets than used in this paper. Those results are in good agreement and differ by less than $0.1 \mathrm{ppmv}$, well within the estimated uncertainties, from our results using the passive subtraction methods with ATLAS and SLIMCAT. Agreement with these previous studies indicates that our estimated ozone losses are reasonable. Finally, we also conclude that the Arctic ozone loss estimates in 2010-2011 are very similar regarding the peak loss altitude and the mixing ratio loss (with maximum differences of 0.5 ppmv, approximately $20 \%$ of the estimated losses) when various instruments, models, and different approaches are utilized.

\section{Summary and conclusions}

This study evaluated the springtime Arctic ozone depletion estimated from various methods for five years between the winters of 2004-2005 and 2012-2013 using the spaceborne ACE-FTS dataset. The estimation methods used are the tracer-tracer correlation, the artificial tracer, the average vortex profile descent, and passive subtraction with ATLAS and SLIMCAT. The Match approach is also a wellestablished method used to estimate ozone depletion. However, we found that with the ACE-FTS dataset, it was not possible to estimate the loss between January and end of March using this method. Due to the orbit of ACE-FTS there is a measurement gap in the Arctic in February that is typically 2-3 weeks, which is too long for the trajectory estimations used for the Match approach. The chemical ozone depletion was estimated, using the mentioned six methods for the Arctic winters of 2004-2005, 2006-2007, 2007-2008, 20092010, and 2010-2011. During all other Arctic winters (20052006, 2008-2009, 2011-2012, and 2012-2013), the Arctic lower stratospheric vortex was disturbed enough that insufficient measurements were recorded inside the polar vortex in March to estimate ozone loss from ACE-FTS measurements.

ACE-FTS provides retrievals of over 30 trace gases; from these, six long-lived tracers were used with the tracer-tracer correlation and average vortex profile descent techniques. We have shown that $\mathrm{CH}_{4}, \mathrm{~N}_{2} \mathrm{O}, \mathrm{HF}$, and $\mathrm{CCl}_{2} \mathrm{~F}_{2}$ perform equally well for these methods. Using OCS or $\mathrm{CCl}_{3} \mathrm{~F}$ as tracers for these approaches has shown the following issues: with ACEFTS OCS, positive descent rates or descent rates that were only half that of the other tracers have been determined, likely due to the limited accuracy of the ACE-FTS OCS retrievals, which have high retrieval fitting errors. Therefore, OCS is not recommended for use as a tracer with the ACEFTS v3.5 dataset to derive Arctic polar ozone loss. ACE-FTS $\mathrm{CCl}_{3} \mathrm{~F}$ has limited coverage compared to other species, and this was not sufficient to estimate ozone depletion using the average vortex descent technique and the artificial tracer correlation method for each year. Also, four different artificial tracers that linearly correlate with ozone were investigated.
Two artificial tracers were identified as suitable tracers for estimating ozone depletion. We found that the combination of $\mathrm{N}_{2} \mathrm{O}, \mathrm{CH}_{4}, \mathrm{CCl}_{3} \mathrm{~F}$, and $\mathrm{CCl}_{2} \mathrm{~F}_{2}$ (Tracer 1), and $\mathrm{N}_{2} \mathrm{O}, \mathrm{CH}_{4}$, OCS, and $\mathrm{CCl}_{3} \mathrm{~F}$ (Tracer 4) work equally well.

Comparisons of the ozone loss estimates from the methods in this study with those obtained from other methods and instruments are in good agreement. This is especially the case for the Arctic winter of 2010-2011, which shows a peak ozone loss of $2.0-2.65 \mathrm{ppmv}$ at $450-475 \mathrm{~K}$ throughout various methods and datasets. Also consistent with previous studies, strong losses were computed for 2004-2005. Our loss estimates are in good agreement with estimates from other studies for March 2005 (Manney et al., 2006; Tilmes et al., 2006; Rösevall et al., 2008). Similar March average ozone losses were seen in March 2007 and 2008, and smaller losses were seen in March 2010 (as shown in Table 1).

Overall, we showed that with one dataset and several ozone loss estimation methods, losses are determined that agree with the estimated uncertainties. The results of the partial-column ozone losses from different methods that have been investigated are, for the most part, within the estimated uncertainties (which are, however, quite large for the correlation methods), except for the maximum loss using the average vortex profile descent technique, which is consistently lower than the five other methods shown in this study. While similar ozone losses were computed for all methods in years with an isolated polar vortex, the passive subtraction methods using either ATLAS or SLIMCAT seem to have smaller computed uncertainties. Note that the uncertainty estimated here is a lower bound on the actual uncertainty, since it does not consider the accumulated uncertainties in model transport until March. The tracer-tracer correlation and artificial tracer techniques have large uncertainties because of the large standard deviation of the early vortex reference function. The estimated partial-column loss uncertainties for the former are approximately twice as large as estimated with the passive subtraction using CTMs and the average vortex profile descent techniques. For a highly disturbed vortex, the passive subtraction methods using CTMs indicate larger ozone loss than the methods that use measurements only, showing that either measurement-only methods underestimate the ozone loss due to unaccounted mixing processes, or the passive subtraction methods using CTMs might overestimate passive ozone. Very little difference was found between using the passive subtraction method with passive ozone from a Lagrangian (ATLAS) and from an Eulerian model (SLIMCAT). For the first time, an evaluation has been performed of these six different ozone loss estimation methods with one dataset. Using the dataset from the space-borne ACE-FTS, we found consistency and good agreement between all methods for winters with a strong and isolated polar vortex. Based on this study, for years with a stable and strong polar vortex, the tracer-tracer technique, the artificial tracer technique, and passive subtraction using both CTMs lead to similar ozone losses and seem to estimate a similar passive ozone profile. 
We also found that from the six different estimation methods presented, the artificial tracer correlation technique and the passive subtraction method (with ATLAS or SLIMCAT) are best suited for estimating the ozone loss in the Arctic polar vortex. Based on the years studied, for years with an unstable polar vortex, we recommend using the passive subtraction technique, since the artificial tracer technique does not account for mixing of extra-polar vortex air. We did not find any significant difference between an Eulerian or a Lagrangian model and found that both types of CTMs seem to compute the Arctic ozone loss equally well.

Data availability. The ACE-FTS Level 2 dataset used in this study can be obtained via the ACE-FTS website (registration required) at http://www.ace.uwaterloo.ca (last access: 26 October 2018) (ACE-FTS, 2017) or upon request from the corresponding author (kaley.walker@utoronto.ca). SLIMCAT output analyzed in this current study is available from the corresponding author (kaley.walker@utoronto.ca) or Martyn Chipperfield (m.chipperfield@leeds.ac.uk) on reasonable request. The ATLAS source code is available on the AWIForge repository (https:// swrepo1.awi.de/, last access: 26 October 2018). Access to the repository is granted on request. ATLAS output analyzed in this current study is also available upon request from the corresponding author (kaley.walker@utoronto.ca).

Supplement. The supplement related to this article is available online at: https://doi.org/10.5194/acp-19-577-2019-supplement.

Author contributions. DG and KAW designed the research and led the writing of the paper. IW and MR provided the ATLAS model run. SSD, MPC and WF provided the SLIMCAT model run. GLM provided the DMPs and assistance with interpretation of results. JL and DT set up the HYSPLIT trajectory runs. All authors participated in the discussion of the results and inputs to the paper.

Competing interests. The authors declare that they have no competing interests.

Acknowledgements. This work was supported by grants from the Canadian Space Agency (CSA) and the Natural Sciences and Engineering Research Council of Canada (NSERC). The Atmospheric Chemistry Experiment (ACE), also known as SCISAT, is a Canadian-led mission mainly supported by CSA and NSERC. We thank ECMWF for providing reanalysis data. The research leading to these results has received funding from the European Community's Seventh Framework Programme (FP7/2007-2013) under grant agreement no. 603557 (Stratoclim). The SLIMCAT modelling was supported by the Natural Environment Research Council (NERC), National Centre for Earth Observations (NCEO) and National Centre for Atmospheric Science (NCAS). The SLIMCAT simulations were performed on the Archer and University of Leeds (Arc2 and N8) HPC systems. Martyn P. Chipperfield was supported by a Royal Society Wolfson Merit Award. The authors thank Peter Bernath for his leadership of the ACE mission and Chris Boone for his development of the ACE retrieval.

Edited by: Jayanarayanan Kuttippurath

Reviewed by: Bjoern-Martin Sinnhuber and two anonymous referees

\section{References}

Adams, C., Strong, K., Batchelor, R. L., Bernath, P. F., Brohede, S., Boone, C., Degenstein, D., Daffer, W. H., Drummond, J. R., Fogal, P. F., Farahani, E., Fayt, C., Fraser, A., Goutail, F., Hendrick, F., Kolonjari, F., Lindenmaier, R., Manney, G., McElroy, C. T., McLinden, C. A., Mendonca, J., Park, J.-H., Pavlovic, B., Pazmino, A., Roth, C., Savastiouk, V., Walker, K. A., Weaver, D., and Zhao, X.: Severe 2011 ozone depletion assessed with 11 years of ozone, $\mathrm{NO}_{2}$, and OClO measurements at $80^{\circ} \mathrm{N}$, Geophys. Res. Lett., 39, L05806, https://doi.org/10.1029/2011GL050478, 2012.

Adams, C., Strong, K., Zhao, X., Bourassa, A. E., Daffer, W. H., Degenstein, D., Drummond, J. R., Farahani, E. E., Fraser, A., Lloyd, N. D., Manney, G. L., McLinden, C. A., Rex, M., Roth, C., Strahan, S. E., Walker, K. A., and Wohltmann, I.: The spring 2011 final stratospheric warming above Eureka: anomalous dynamics and chemistry, Atmos. Chem. Phys., 13, 611-624, https://doi.org/10.5194/acp-13-611-2013, 2013.

Andrews, D. G.: Some comparisons between the middle atmosphere dynamics for the southern and northern hemispheres, Pure Appl. Geophys., 130, 213-232, 1989.

Arnold, F.: Stratospheric aerosol increases and ozone destruction: Implications from mass spectrometer measurements, Ber. Bunsen Ges. Phys. Chem., 96, 339-350, 1992.

Arnone, E., Castelli, E., Papandrea, E., Carlotti, M., and Dinelli, B. M.: Extreme ozone depletion in the 2010-2011 Arctic winter stratosphere as observed by MIPAS/ENVISAT using a 2 D tomographic approach, Atmos. Chem. Phys., 12, 9149-9165, https://doi.org/10.5194/acp-12-9149-2012, 2012.

Balis, D., Isaksen, I. S. A., Zerefos, C., Zyrichidou, I., Eleftheratos, K., Tourpali, K., Bojkov, R., Rognerud, B., Stordal, F., Søvde, O. A., and Orsolini, Y.: Observed and modelled record ozone decline over the Arctic during winter/spring 2011, Geophys. Res. Lett., 38, L23801, https://doi.org/10.1029/2011GL049259, 2011.

Barkley, M. P., Palmer, P. I., Boone, C. D., Bernath, P. F., and Sunthraralingam, P.: Global distributions of carbonyl sulfide in the upper troposphere and stratosphere, Geophys. Res. Lett., 35 , L14810, https://doi.org/10.1029/2008GL034270, 2008.

Bernath, P. F., McElroy, C. T., Abrams, M. C., Boone, C. D, Butler, M., Camy-Peyret, C., Carleer, M., Clerbaux, C., Coheur, P.-F., Colin, R., DeCola, P., DeMazière, M., Drummond, J. R., Dufour, D., Evans, W. F. J., Fast, H., Fussen, D., Gilbert, K., Jennings, D. E., Llewellyn, E. J., Lowe, R. P., Mahieu, E., McConnell, J. C., McHugh, M., McLeod, S. D., Michaud, R., Midwinter, C., Nassar, R., Nichitiu, F., Nowlan, C., Rinsland, C. P., Rochon, Y. J., Rowlands, N., Semeniuk, K., Simon, P., Skelton, R., Sloan, J. J., Soucy, M.-A., Strong, K., Tremblay, P., Turnbull, D., Walker, K. A., Walkty, I., Wardle, D. A., Wehrle, V., Zander, R., and Zou, J.: Atmospheric Chemistry Experiment 
(ACE): Mission overview, Geophys. Res. Lett., 32, L15S01, https://doi.org/10.1029/2005GL022386, 2005.

Bernhard, G., Manney, G., Fioletov, V., Grooß, J.-U., Heikkilä, A., Johnsen, B., Koskela, T., Lakkala, K., Müller, R., Myhre, C. L., and Rex, M.: Ozone and UV Radiation, in: State of the Climate 2011, B. Am. Meteor. Soc., 93, S129-S132, 2012.

Boone, C. D., Nassar, R., Walker, K. A., Rochon, Y., McLeod, S. D., Rinsland, C. P., and Bernath, P. F.: Retrievals for the atmospheric chemistry experiment Fourier-transform spectrometer, Appl. Optics, 44, 7218-7231, 2005.

Boone, C. D., Walker, K. A., and Bernath, P. F.: Version 3 Retrievals for the Atmospheric Chemistry Experiment Fourier Transform Spectrometer (ACE-FTS), The Atmospheric Chemistry Experiment ACE at 10: A Solar Occultation Anthology, edited by: Bernath, P. F., A. Deepak Publishing, Hampton, Virginia, USA, 2013, 103-127, 2013.

Brakebusch, M., Randall, C. E., Kinnison, D. E., Tilmes, S., Santee, M. L., and Manney, G. L.: Evaluation of Whole Atmosphere Community Climate Model simulations of ozone during Arctic winter 2004-2005, J. Geophys. Res., 118, 2673-2688, https://doi.org/10.1002/jgrd.50226, 2013.

Brown, A. T., Volk, C. M., Schoeberl, M. R., Boone, C. D., and Bernath, P. F.: Stratospheric lifetimes of CFC-12, $\mathrm{CCl}_{4}$, $\mathrm{CH}_{4}, \mathrm{CH}_{3} \mathrm{Cl}$ and $\mathrm{N}_{2} \mathrm{O}$ from measurements made by the Atmospheric Chemistry Experiment-Fourier Transform Spectrometer (ACE-FTS), Atmos. Chem. Phys., 13, 6921-6950, https://doi.org/10.5194/acp-13-6921-2013, 2013.

Carslaw, K. S., Luo, B. P., Clegg, S. L., Peter, T., Brimblecombe, P., and Crutzen, P. J.: Stratospheric aerosol growth and $\mathrm{HNO}_{3}$ gas phase depletion from coupled $\mathrm{HNO}_{3}$ and water uptake by liquid particles, Geophys. Res. Lett., 21, 2479-2482, https://doi.org/10.1029/94GL02799, 1994.

Chandran, A., Garcia, R. R., Collins, R. L., and Chang, L. C.: Secondary planetary waves in the middle and upper atmosphere following the stratospheric sudden warming event of January 2012, Geophys. Res. Lett., 40, 1861-1867, https://doi.org/10.1002/grl.50373, 2013.

Chipperfield, M. P.: New version of the TOMCAT/SLIMCAT offline chemical transport model: Intercomparison of stratospheric tracer experiments, Q. J. Roy. Meteorol. Soc., 132, 1179-1203, 2006.

Chipperfield, M. P. and Jones, R. L.: Relative influences of atmospheric chemistry and transport on Arctic ozone trends, Nature, 400, 551-554, https://doi.org/10.1038/22999, 1999.

Chipperfield, M. P., Dhomse, S. S., Feng, W., McKenzie, R. L., Velders, G. J. M., and Pyle, J. A.: Quantifying the ozone and ultraviolet benefits already achieved by the Montreal Protocol, Nat. Commun., 6, 7233, https://doi.org/10.1038/ncomms8233, 2015.

Coy, L. and Pawson, S.: The major stratospheric sudden warming of January 2013: analyses and forecasts in the GEOS-5 data assimilation system, Mon. Weather Rev., 143, 491-510, 2015.

Coy, L., Eckermann, S., and Hoppel, K.: Planetary wave breaking and tropospheric forcing as seen in the stratospheric sudden warming of 2006, J. Atmos. Sci., 66, 495-507, https://doi.org/10.1175/2008JAS2784.1, 2009.

Crutzen, P. J. and Arnold, F.: Nitric acid cloud formation in the cold Antarctic stratosphere: A major cause for the springtime "ozone hole", Nature, 324, 651-655, 1986.
Dee, D. P., Uppala, S. M., Simmons, A. J., Berrisford, P., Poli, P., Kobayashi, S., Andrae, U., Balmaseda, M. A., Balsamo, G., Bauer, P., Bechtold, P., Beljaars, A. C. M., van de Berg, L., Bidlot, J., Bormann, N., Delsol, C., Dragani, R., Fuentes, M., Geer, A. J., Haimberger, L., Healy, S. B., Hersbach, H., Holm, E. V., Isaksen, L., Kallberg, P., Koehler, M., Matricardi, M., McNally, A. P., Monge-Sanz, B. M., Morcrette, J. J., Park, B. K., Peubey, C., de Rosnay, P., Tavolato, C., Thepaut, J. N., and Vitart, F.: The ERA-Interim reanalysis: configuration and performance of the data assimilation system, Q. J. Roy. Meteor. Soc., 137, 553-597, 2011.

De Mazière, M., Vigouroux, C., Bernath, P. F., Baron, P., Blumenstock, T., Boone, C., Brogniez, C., Catoire, V., Coffey, M., Duchatelet, P., Griffith, D., Hannigan, J., Kasai, Y., Kramer, I., Jones, N., Mahieu, E., Manney, G. L., Piccolo, C., Randall, C., Robert, C., Senten, C., Strong, K., Taylor, J., Tétard, C., Walker, K. A., and Wood, S.: Validation of ACE-FTS v2.2 methane profiles from the upper troposphere to the lower mesosphere, Atmos. Chem. Phys., 8, 2421-2435, https://doi.org/10.5194/acp-8-24212008, 2008.

Dhomse, S. S., Chipperfield, M. P., Feng, W., Ball, W. T., Unruh, Y. C., Haigh, J. D., Krivova, N. A., Solanki, S. K., and Smith, A. K.: Stratospheric $\mathrm{O}_{3}$ changes during 2001-2010: the small role of solar flux variations in a chemical transport model, Atmos. Chem. Phys., 13, 10113-10123, https://doi.org/10.5194/acp-1310113-2013, 2013.

Dhomse, S. S., Emmerson, K. M., Mann, G. W., Bellouin, N., Carslaw, K. S., Chipperfield, M. P., Hommel, R., Abraham, N. L., Telford, P., Braesicke, P., Dalvi, M., Johnson, C. E., O'Connor, F., Morgenstern, O., Pyle, J. A., Deshler, T., Zawodny, J. M., and Thomason, L. W.: Aerosol microphysics simulations of the Mt. Pinatubo eruption with the UM-UKCA composition-climate model, Atmos. Chem. Phys., 14, 1122111246, https://doi.org/10.5194/acp-14-11221-2014, 2014.

Dhomse, S. S., Chipperfield, M. P., Feng, W., Hossaini, R., Mann, G. W., and Santee, M. L.: Revisiting the hemispheric asymmetry in midlatitude ozone changes following the Mount Pinatubo eruption: A 3-D model study, Geophys. Res. Lett., 42, 30383047, https://doi.org/10.1002/2015GL063052, 2015.

Dörnbrack, A., Pitts, M. C., Poole, L. R., Orsolini, Y. J., Nishii, K., and Nakamura, H.: The 2009-2010 Arctic stratospheric wintergeneral evolution, mountain waves and predictability of an operational weather forecast model, Atmos. Chem. Phys., 12, 36593675, https://doi.org/10.5194/acp-12-3659-2012, 2012.

Draxler, R. and Hess, G.: Description of the HYSPLIT4 modeling system, NOAA Technical Memorandum, ERL, ARL-224, 2004.

Drdla, K. and Müller, R.: Temperature thresholds for chlorine activation and ozone loss in the polar stratosphere, Ann. Geophys., 30, 1055-1073, https://doi.org/10.5194/angeo-30-10552012, 2012.

Dufour, G., Boone, C. D., and Bernath, P. F.: First measurements of CFC-113 and HCFC-142b from space using ACE-FTS infrared spectra, Geophys. Res. Lett., 32, L15S09, https://doi.org/10.1029/2005GL022422, 2005.

Dunkerton, T. J. and Delisi, D. P.: Evolution of potential vorticity in the winter stratosphere of January-February 1979, J. Geophys. Res., 91, 1199-1208, 1986.

Dupuy, E., Walker, K. A., Kar, J., Boone, C. D., McElroy, C. T., Bernath, P. F., Drummond, J. R., Skelton, R., McLeod, S. D., 
Hughes, R. C., Nowlan, C. R., Dufour, D. G., Zou, J., Nichitiu, F., Strong, K., Baron, P., Bevilacqua, R. M., Blumenstock, T., Bodeker, G. E., Borsdorff, T., Bourassa, A. E., Bovensmann, H., Boyd, I. S., Bracher, A., Brogniez, C., Burrows, J. P., Catoire, V., Ceccherini, S., Chabrillat, S., Christensen, T., Coffey, M. T., Cortesi, U., Davies, J., De Clercq, C., Degenstein, D. A., De Mazière, M., Demoulin, P., Dodion, J., Firanski, B., Fischer, H., Forbes, G., Froidevaux, L., Fussen, D., Gerard, P., GodinBeekmann, S., Goutail, F., Granville, J., Griffith, D., Haley, C. S., Hannigan, J. W., Höpfner, M., Jin, J. J., Jones, A., Jones, N. B., Jucks, K., Kagawa, A., Kasai, Y., Kerzenmacher, T. E., Kleinböhl, A., Klekociuk, A. R., Kramer, I., Küllmann, H., Kuttippurath, J., Kyrölä, E., Lambert, J.-C., Livesey, N. J., Llewellyn, E. J., Lloyd, N. D., Mahieu, E., Manney, G. L., Marshall, B. T., McConnell, J. C., McCormick, M. P., McDermid, I. S., McHugh, M., McLinden, C. A., Mellqvist, J., Mizutani, K., Murayama, Y., Murtagh, D. P., Oelhaf, H., Parrish, A., Petelina, S. V., Piccolo, C., Pommereau, J.-P., Randall, C. E., Robert, C., Roth, C., Schneider, M., Senten, C., Steck, T., Strandberg, A., Strawbridge, K. B., Sussmann, R., Swart, D. P. J., Tarasick, D. W., Taylor, J. R., Tétard, C., Thomason, L. W., Thompson, A. M., Tully, M. B., Urban, J., Vanhellemont, F., Vigouroux, C., von Clarmann, T., von der Gathen, P., von Savigny, C., Waters, J. W., Witte, J. C., Wolff, M., and Zawodny, J. M.: Validation of ozone measurements from the Atmospheric Chemistry Experiment (ACE), Atmos. Chem. Phys., 9, 287-343, https://doi.org/10.5194/acp-9287-2009, 2009.

Eckert, E., Laeng, A., Lossow, S., Kellmann, S., Stiller, G., von Clarmann, T., Glatthor, N., Höpfner, M., Kiefer, M., Oelhaf, H., Orphal, J., Funke, B., Grabowski, U., Haenel, F., Linden, A., Wetzel, G., Woiwode, W., Bernath, P. F., Boone, C., Dutton, G. S., Elkins, J. W., Engel, A., Gille, J. C., Kolonjari, F., Sugita, T., Toon, G. C., and Walker, K. A.: MIPAS IMK/IAA CFC-11 $\left(\mathrm{CCl}_{3} \mathrm{~F}\right)$ and CFC-12 $\left(\mathrm{CCl}_{2} \mathrm{~F}_{2}\right)$ measurements: accuracy, precision and long-term stability, Atmos. Meas. Tech., 9, 3355-3389, https://doi.org/10.5194/amt-9-3355-2016, 2016.

Esler, J. G. and Waugh, D. W.: A method for estimating the extent of denitrification of arctic polar vortex air from tracer-tracer scatter plots, J. Geophys. Res., 107, 4169, https://doi.org/10.1029/2001JD001071, 2002.

Feng, W., Chipperfield, M. P., Davies, S., von der Gathen, P., Kirö, E., Volk, C. M., Ulanovsky, A., and Belyaev, G.: Large chemical ozone loss in 2004/2005 Arctic winter/spring, Geophys. Res. Lett., 34, L09803, https://doi.org/10.1029/2006GL029098, 2007.

Fromm, M. D., Bevilacqua, R. M., Hornstein, J., Shettle, E. P., Hoppel, K., and Lumpe, J. D.: An analysis of Polar Ozone and Aerosol Measurement POAM II Arctic stratospheric cloud observations, 1993-1996, J. Geophys. Res., 104, 24341-24357, 1999.

Goutail, F., Pommereau, J.-P., Lefèvre, F., van Roozendael, M., Andersen, S. B., Kåstad Høiskar, B.-A., Dorokhov, V., Kyrö, E., Chipperfield, M. P., and Feng, W.: Early unusual ozone loss during the Arctic winter 2002/2003 compared to other winters, Atmos. Chem. Phys., 5, 665-677, https://doi.org/10.5194/acp-5665-2005, 2005.

Harris, N. R. P., Rex, M., Goutail, F., Knudsen, B. M., Manney, G. L., Müller, R., and von der Gathen, P.: Comparison of empirically derived ozone loss rates in the Arctic vortex, J. Geophys. Res., 107, 8264, https://doi.org/10.1029/2001JD000482, 2002.
Harrison, J. J., Chipperfield, M. P., Boone, C. D., Dhomse, S. S., Bernath, P. F., Froidevaux, L., Anderson, J., and Russell III, J.: Satellite observations of stratospheric hydrogen fluoride and comparisons with SLIMCAT calculations, Atmos. Chem. Phys., 16, 10501-10519, https://doi.org/10.5194/acp-16-105012016, 2016.

Hoffmann, L., Hoppe, C. M., Müller, R., Dutton, G. S., Gille, J. C., Griessbach, S., Jones, A., Meyer, C. I., Spang, R., Volk, C. M., and Walker, K. A.: Stratospheric lifetime ratio of CFC-11 and CFC-12 from satellite and model climatologies, Atmos. Chem. Phys., 14, 12479-12497, https://doi.org/10.5194/acp-14-124792014, 2014.

Isaksen, I. S. A., Zerefos, C., Wang, W.-C., Balis, D., Eleftheratos, K., Rognerud, B., Stordal, F., Berntsen, T. K., LaCasce, J. H., Søvde, O. A., Olivié, D., Orsolini, Y. J., Zyrichidou, I., Prather, M., and Tuinder, O. N. E.: Attribution of the Arctic ozone column deficit in March 2011, Geophys. Res. Lett., 39, L24810, https://doi.org/10.1029/2012GL053876, 2012.

Jin, J. J., Semeniuk, K., Manney, G. L., Jonsson, A. I., Beagley, S. R., McConnell, J. C., Dufour, Nassar, R., Boone, C. D., Walker, K. A., Bernath, P. F., and Rinsland, C. P.: Severe Arctic ozone loss in the winter 2004/2005: observations from ACE-FTS, Geophys. Res. Lett., 33, L15801, https://doi.org/10.1029/2006GL026752, 2006.

Kalnay, E., Kanamitsu, M., Kistler, R., Collins, W., Deaven, D., Gandin, L., Iredell, M., Saha, S., White, G., Woollen, G., Zhu, Y., Leetmaa, A., Reynolds, R., Chelliah, M., Ebisuzaki, W., Higgins, W., Janowiak, J., Mo, K. C., Ropelewski, C., Wang, J., Jenne, R., and Joseph, D.: The NCEP/NCAR 40-year reanalysis project, B. Am. Meteor. Soc., 77, 437-470, 1996.

Kuttippurath, J. and Nikulin, G.: A comparative study of the major sudden stratospheric warmings in the Arctic winters 2003/2004-2009/2010, Atmos. Chem. Phys., 12, 8115-8129, https://doi.org/10.5194/acp-12-8115-2012, 2012.

Kuttippurath, J., Godin-Beekmann, S., Lefèvre, F., and Goutail, F.: Spatial, temporal, and vertical variability of polar stratospheric ozone loss in the Arctic winters 2004/2005-2009/2010, Atmos. Chem. Phys., 10, 9915-9930, https://doi.org/10.5194/acp10-9915-2010, 2010.

Kuttippurath, J., Godin-Beekmann, S., Lefèvre, F., Nikulin, G., Santee, M. L., and Froidevaux, L.: Record-breaking ozone loss in the Arctic winter 2010/2011: comparison with 1996/1997, Atmos. Chem. Phys., 12, 7073-7085, https://doi.org/10.5194/acp12-7073-2012, 2012.

Labitzke, K. and Kunze, M.: On the remarkable Arctic winter in 2008/2009, J. Geophys. Res., 114, D00I02, https://doi.org/10.1029/2009JD012273.

Lindenmaier, R., Strong, K., Batchelor, R. L., Chipperfield, M. P., Daffer, W. H., Drummond, J. R., Duck, T. J., Fast, H., Feng, W., Fogal, P. F., Kolonjari, F., Manney, G. L., Manson, A., Meek, C., Mittermeier, R. L., Nott, G. J., Perro, C., and Walker, K. A.: Unusually low ozone, $\mathrm{HCl}$, and $\mathrm{HNO}_{3}$ column measurements at Eureka, Canada during winter/spring 2011, Atmos. Chem. Phys., 12, 3821-3835, https://doi.org/10.5194/acp12-3821-2012, 2012.

Livesey, N. J., Santee, M. L., and Manney, G. L.: A Matchbased approach to the estimation of polar stratospheric ozone loss using Aura Microwave Limb Sounder observations, At- 
mos. Chem. Phys., 15, 9945-9963, https://doi.org/10.5194/acp15-9945-2015, 2015.

Lowe, D. and MacKenzie, A. R.: Polar stratospheric cloud microphysics and chemistry, J. Atmos. Sol.-Terr. Phys., 70, 13-40, 2008.

Mahieu, E., Duchatelet, P., Demoulin, P., Walker, K. A., Dupuy, E., Froidevaux, L., Randall, C., Catoire, V., Strong, K., Boone, C. D., Bernath, P. F., Blavier, J.-F., Blumenstock, T., Coffey, M., De Mazière, M., Griffith, D., Hannigan, J., Hase, F., Jones, N., Jucks, K. W., Kagawa, A., Kasai, Y., Mebarki, Y., Mikuteit, S., Nassar, R., Notholt, J., Rinsland, C. P., Robert, C., Schrems, O., Senten, C., Smale, D., Taylor, J., Tétard, C., Toon, G. C., Warneke, T., Wood, S. W., Zander, R., and Servais, C.: Validation of ACEFTS v2.2 measurements of $\mathrm{HCl}, \mathrm{HF}, \mathrm{CCl}_{3} \mathrm{~F}$ and $\mathrm{CCl}_{2} \mathrm{~F}_{2}$ using space-, balloon- and ground-based instrument observations, Atmos. Chem. Phys., 8, 6199-6221, https://doi.org/10.5194/acp-86199-2008, 2008.

Manney, G. L., Froidevaux, L., Waters, J. W., Zurek, R. W., Read, W. G., Elson, L. S., Kumer, J. B., Mergenthaler, J. L., Roche, A. E., O’Neill, A., Harwood, R. S., Mackenzie, I., and Swinbank, R.: Chemical depletion of ozone in the Arctic lower stratosphere during winter 1992-93, Nature, 370, 429434, https://doi.org/10.1038/370429a0, 1994a.

Manney, G. L., Zurek, R. W., O’Neill, A. O., and Swinbank, R.: On the motion of air through the stratospheric polar vortex, J. Atmos. Sci., 51, 2973-2994, 1994b.

Manney, G. L., Zurek, R. W., Froidevaux, L.,Waters, J. W., O’Neill, A., and Swinbank, R.: Lagrangian transport calculations using UARS data. Part II - Ozone, J. Atmos. Sci., 52, 3069-3081, 1995.

Manney, G. L., Froidevaux, L., Santee, M. L., Livesey, N. J., Sabutis, J. L., and Waters, J. W.: Variability of ozone loss during Arctic winter (1999-2000) estimated from UARS Microwave Limb Sounder measurements, J. Geophys. Res., 108, 15 pp., https://doi.org/10.1029/2002JD002634, 2003.

Manney, G. L., Sabutis, J. L., Allen, D. R., Lahoz, W. A., Scaife, A. A., Pawson, S., Randall, C. E., Naujokat, B., and Swinbank, R.: Simulations of dynamics and transport during the September 2002 Antarctic major warming, J. Atmos. Sci., 62, 690-707, 2005.

Manney, G. L., Santee, M. L., Froidevaux, L., Hoppel, K., Livesey, N. J., and Waters, J. W.: EOS MLS observations of ozone loss in the 2004-2005 Arctic winter, Geophys. Res. Lett., 33, L04802, https://doi.org/10.1029/2005GL024494, 2006.

Manney, G. L., Daffer, W. H., Zawodny, J. M., Bernath, P. F., Hoppel, K. W., Walker, K. A., Knosp, B. W., Boone, C., Remsberg, E. E., Santee, M. L., Harvey, V. L., Pawson, S., Jackson, D. R., Deaver, L., McElroy, C. T., McLinden, C. A., Drummond, J. R., Pumphrey, H. C., Lambert, A., Schwartz, M. J., Froidevaux, L., McLeod, S., Takacs, L. L., Suarez, M. J., Trepte, C. R., Cuddy, D. C., Livesey, N. J., Harwood, R. S., and Waters, J. W.: Solar occultation satellite data and derived meteorological products: Sampling issues and comparisons with Aura Microwave Limb Sounder, J. Geophys. Res., 112, D24550, https://doi.org/10.1029/2007JD008709, 2007.

Manney, G. L., Krüger, K., Pawson, S., Minschwaner, K., Schwartz, M. J., Daffer, W. H., Livesey, N. J., Mlynczak, M. G., Remsberg, E. E., Russell, J. M., and Waters, J. W.: The evolution of the stratopause during the 2006 major warming: Satellite data and assimilated meteorological analyses, J. Geophys. Res., 113, D11115, https://doi.org/10.1029/2007JD009097, 2008.

Manney, G. L., Daffer, W. H., Strawbridge, K. B., Walker, K. A., Boone, C. D., Bernath, P. F., Kerzenmacher, T., Schwartz, M. J., Strong, K., Sica, R. J., Krüger, K., Pumphrey, H. C., Lambert, A., Santee, M. L., Livesey, N. J., Remsberg, E. E., Mlynczak, M. G., and Russell III, J. R.: The high Arctic in extreme winters: vortex, temperature, and MLS and ACE-FTS trace gas evolution, Atmos. Chem. Phys., 8, 505-522, https://doi.org/10.5194/acp-8505-2008, 2008.

Manney, G. L., Harwood, R. S., MacKenzie, I. A., Minschwaner, K., Allen, D. R., Santee, M. L., Walker, K. A., Hegglin, M. I., Lambert, A., Pumphrey, H. C., Bernath, P. F., Boone, C. D., Schwartz, M. J., Livesey, N. J., Daffer, W. H., and Fuller, R. A.: Satellite observations and modeling of transport in the upper troposphere through the lower mesosphere during the 2006 major stratospheric sudden warming, Atmos. Chem. Phys., 9, 47754795, https://doi.org/10.5194/acp-9-4775-2009, 2009.

Manney, G. L., Schwartz, M. J., Krüger, K., Santee, M. L., Pawson, S., Lee, J. N., Daffer, W. H., Fuller, R. A., and Livesey, N. J.: Aura Microwave Limb Sounder observations of dynamics and transport during the record-breaking 2009 Arctic stratospheric major warming, Geophys. Res. Lett., 36, L12815, https://doi.org/10.1029/2009GL038586, 2009.

Manney, G. L., Santee, M. L., Rex, M., Livesey, N. J., Pitts, M. C., Veefkind, P., Nash, E. R., Wohltmann, I., Lehmann, R., Froidevaux, L., Poole, L. R., Schoeberl, M. R., Haffner, D. P., Davies, J., Dorokhov, V., Gernandt, H., Johnson, B., Kivi, R., Kyrö, E., Larsen, N., Levelt, P. F., Makshtas, A., McElroy, C. T., Nakajima, H., Parrondo, M. C., Tarasick, D. W., von der Gathen, P., Walker, K. A., and Zinoviev, N. S.: Unprecedented Arctic Ozone Loss in 2011, Nature, 478, 469-475, https://doi.org/10.1038/nature10556, 2011.

Manney, G. L., Lawrence, Z. D., Santee, M. L., Livesey, N. J., Lambert, A., and Pitts, M. C.: Polar processing in a split vortex: Arctic ozone loss in early winter 2012/2013, Atmos. Chem. Phys., 15, 5381-5403, https://doi.org/10.5194/acp-15-5381-2015, 2015.

McCormick, M. P., Steele, H. M., Hamill, P., Chu, W. P., and Swissler, T. J.: Polar stratospheric cloud sightings by SAM II, J. Atmos. Sci., 39, 1387-1397, 1982.

McElroy, M. B., Salawitch, R. J., Wofsy, S. C., and Logan, J. A.: Reductions of Antarctic ozone due to synergistic interactions of chlorine and bromine, Nature, 321, 759-762, 1986.

Michelsen, H. A., Manney, G. L., Gunson, M. R., Rinsland, C. P., and Zander, R.: Correlations of stratospheric abundances of $\mathrm{CH}_{4}$ and $\mathrm{N}_{2} \mathrm{O}$ derived from ATMOS measurements, Geophys. Res. Lett., 25, 2777-2780, 1998.

Molina, L. T. and Molina, M. J.: Production of $\mathrm{Cl}_{2} \mathrm{O}_{2}$ from the selfreaction of the ClO radical, J. Phys. Chem., 91, 433-436, 1987.

Montzka, S. A., Calvert, P., Hall, B. D., Elkins, J. W., Conway, T. J., Tans, P. P., and Sweeney, C.: On the global distribution, seasonality, and budget of atmospheric carbonyl sulfide (COS) and some similarities to $\mathrm{CO}_{2}$, J. Geophys. Res., 112, D09302, https://doi.org/10.1029/2006JD007665, 2007.

Müller, R., Crutzen, P. J., Grooß, J.-U., Brühl, C., Russell III, J. M., Gernandt, H., McKenna, D. S., and Tuck, A. F.: Severe chemical ozone loss in the Arctic during the winter of 1995-96, Nature, 389, 709-712, 1997. 
Müller, R., Schmidt, U., Engel, A., McKenna, D., and Proffitt, M.: The $\mathrm{O}_{3} / \mathrm{N}_{2} \mathrm{O}$ relationship from balloon-borne observations as a measure of Arctic ozone loss in 1991-1992, Q. J. Roy. Meteor. Soc., 127, 1389-1412, 2001.

Müller, R., Tilmes, S., Grooß, J.-U., McKenna, D. S., Müller, M., Schmidt, U., Toon, G. C., Stachnik, R. A., Margitan, J. J., Elkins, J. W., Arvelius, J., and Russell III, J. M.: Chlorine activation and chemical ozone loss deduced from HALOE and balloon measurements in the Arctic during the winter of 1999-2000, J. Geophys. Res., 108, 8302, https://doi.org/10.1029/2001JD001423, 2003

Müller, R., Tilmes, S., Konopka, P., Grooß, J.-U., and Jost, H.J.: Impact of mixing and chemical change on ozone-tracer relations in the polar vortex, Atmos. Chem. Phys., 5, 3139-3151, https://doi.org/10.5194/acp-5-3139-2005, 2005.

Müller, R., Tilmes, S., Grooß, J.-U., Engel, A., Oelhaf, H., Wetzel, G., Huret, N., Pirre, M., Catoire, V., Toon, G., and Nakajima, H.: Impact of mesospheric intrusions on ozone-tracer relations in the stratospheric polar vortex, J. Geophys. Res., 112, D23307, https://doi.org/10.1029/2006JD008315, 2007.

Pitts, M. C., Thomason, L. W., Poole, L. R., and Winker, D. M.: Characterization of Polar Stratospheric Clouds with spaceborne lidar: CALIPSO and the 2006 Antarctic season, Atmos. Chem. Phys., 7, 5207-5228, https://doi.org/10.5194/acp-7-5207-2007, 2007

Pitts, M. C., Poole, L. R., and Thomason, L. W.: CALIPSO polar stratospheric cloud observations: second-generation detection algorithm and composition discrimination, Atmos. Chem. Phys., 9, 7577-7589, https://doi.org/10.5194/acp-9-7577-2009, 2009.

Pitts, M. C., Poole, L. R., Lambert, A., and Thomason, L. W.: An assessment of CALIOP polar stratospheric cloud composition classification, Atmos. Chem. Phys., 13, 2975-2988, https://doi.org/10.5194/acp-13-2975-2013, 2013.

Plumb, R. A.: Tracer interrelationships in the stratosphere, Rev. Geophys., 45, RG4005, https://doi.org/10.1029/2005RG000179, 2007.

Plumb, R. A. and Ko, M. K. W.: Interrelationships between mixing ratios of long-lived stratospheric constituents, J. Geophys. Res., 97, 10145-10156, https://doi.org/10.1029/92JD00450, 1992.

Plumb, R. A., Waugh, D. W., and Chipperfield, M. P.: The effects of mixing on tracer relationships in the polar vortices, J. Geophys. Res., 105, 10047-10062, https://doi.org/10.1029/1999JD901023, 2000.

Plumb, R. A., Heres, W., Neu, J. L., Mahowald, N. M., del Corral, J., Toon, G. C., Ray, E., Moore, F., and Andrews, A. E.: Global tracer modeling during SOLVE: Highlatitude descent and mixing, J. Geophys. Res., 108, 8309, https://doi.org/10.1029/2001JD001023, 2003.

Portmann, R. W., Solomon, S., Garcia, R. R., Thomason, L. W., Poole, L. R., and McCormick, M. P.: Role of aerosol variations in anthropogenic ozone depletion in the polar regions, J. Geophys. Res., 101, 22991-23006, 1996.

Poole, L. R. and McCormick, M. P.: Airborne lidar observations of arctic polar stratospheric clouds: indications of two distinct growth stages, Geophys. Res. Lett., 15, 21-23, 1988.

Proffitt, M. H., Aikin, K., Margitan, J. J., Loewenstein, M., Podolske, J. R., Weaver, A., Chan, K. R., Fast, H., and Elkins, J. W.: Ozone loss inside the northern polar vortex during the 19911992 winter, Science, 261, 1150-1154, 1993.
Ray, E. A., Moore, F. L., Elkins, J. W., Hurst, D. F., Romashkin, P. A., Dutton, G. S., and Fahey, D. W.: Descent and mixing in the 1999-2000 northern polar vortex inferred from in situ tracer measurements, J. Geophys. Res., 107, 8285, https://doi.org/10.1029/2001JD000961, 2002.

Rex, M., von der Gathen, P., Harris, N. R. P., Lucic, D., Knudsen, B. M., Braathen, G. O., Reid, S. J., De Backer, H., Claude, H., Fabian R., Fast, H., Gil, M., Kyrö, E., Mikkelsen, I. S., Rummukainen, M., Smit, H. G., Stähelin, J., Varotsos, C., and Zaitcev, I.: In situ measurements of stratospheric ozone depletion rates in the Arctic winter 1991/1992: A Lagrangian approach, J Geophys. Res., 103, 5843-5853, 1998.

Rex, M., Salawitch, R. J. Harris, N. R. P., von der Gathen, P., Braathen, G. O., Schulz, A., Deckelmann, H., Chipperfield, M., Sinnhuber, B.-M., Reimer, E., Alfier, R., Bevilacqua, R., Hoppel, K., Fromm, M., Lumpe, J., Küllmann, H., Kleinböhl, A., Bremer, H., von König, M., Künzi, K., Toohey, D., Vömel, H., Richard, E., Aikin, K., Jost, H., Greenblatt, J. B., Loewenstein, M., Podolske, J. R., Webster, C. R., Flesch, G. J., Scott, D. C., Herman, R. L., Elkins, J. W., Ray, E. A., Moore, F. L., Hurst, D. F., Romashkin, P., Toon, G. C., Sen, B., Margitan, J. J., Wennberg, P., Neuber, R., Allart, M., Bojkov, B. R., Claude, H., Davies, J., Davies, W., De Backer, H., Dier, H., Dorokhov, V., Fast, H., Kondo, Y., Kyrö, E., Litynska, Z., Mikkelsen, I. S., Molyneux, M. J., Moran, E., Nagai, T., Nakane, H., Parrondo, C., Ravegnani, F., Skrivankova, P., Viatte, P., and Yushkov, V.: Chemical depletion of Arctic ozone in winter 1999/2000, J. Geophys. Res., 107, 8276, https://doi.org/10.1029/2001JD000533, 2002.

Rex, M., Salawitch, R. J., von der Gathen, P., Harris, N. R. P., Chipperfield, M. P., and Naujokat, B.: Arctic ozone loss and climate change, Geophys. Res. Lett., 31, L04116, https://doi.org/10.1029/2003GL018844, 2004.

Richard, E. C., Aikin, K. C., Andrews, A. E., Daube, B. C., Gerbig, C., Wofsy, S. C., Romashkin, P. A., Hurst, D. F., Ray, E. A., Moore, F. L., Elkins, J. W., Deshler, T., and Toon, G. C.: Severe chemical ozone loss in the Arctic polar vortex during winter 1999-2000 inferred from in-situ airborne measurements, Geophys. Res. Lett., 28, 2197-2000, 2001.

Rienecker, M. M., Suarez, M. J., Todling, R., Bacmeister, J., Takacs, L., Liu, H.-C., Gu, W., Sienkiewicz, M., Koster, R. D., Gelaro, R., Stajner, I., and Nielsen, J. E.: The GEOS-5 data assimilation system - documentation of versions 5.0.1, 5.1.0, and 5.2.0, NASA Tech. Memo., TM-2008-104606, 27, 2008.

Rösevall, J. D., Murtagh, D. P., Urban, J., Feng, W., Eriksson, P., and Brohede, S.: A study of ozone depletion in the 2004/2005 Arctic winter based on data from Odin/SMR and Aura/MLS, J. Geophys. Res., 113, D13301, https://doi.org/10.1029/2007JD009560, 2008.

Salawitch, R. J., Margitan, J. J., Sen, B., Toon, G. C., Osterman, G. B., Rex, M., Elkins, J. W., Ray, E. A., Moore, F. L., Hurst, D. F., Romashkin, P. A., Bevilacqua, R. M., Hoppel, K., Richard, E. C., and Bui, T. P.: Chemical loss of ozone during the Arctic winter of 1999-2000: an analysis based on balloon-borne observations, J. Geophys. Res., 107, 8269, https://doi.org/10.1029/2001JD000620, 2002.

Sankey, D. and Shepherd, T. G., Correlations of longlived chemical species in a middle atmosphere gen- 
eral circulation model, J. Geophys. Res., 108, 4494, https://doi.org/10.1029/2002JD002799, 2003.

Schoeberl, M. R. and Hartmann, D. L.: The dynamics of the stratospheric polar vortex and its relation to springtime ozone depletions, Science, 251, 46-52, 1991.

Schoeberl, M. R., Lait, L. R., Newman, P. A., and Rosenfield, J. E.: The structure of the polar vortex, J. Geophys. Res., 97, 78597882, 1992.

Sheese, P. E., Boone, C. D., and Walker, K. A.: Detecting physically unrealistic outliers in ACE-FTS atmospheric measurements, Atmos. Meas. Tech., 8, 741-750, https://doi.org/10.5194/amt-8741-2015, 2015.

Sheese, P. E., Walker, K. A., Boone, C. D., Bernath, P. F., Froidevaux, L., Funke, B., Raspollini, P., and von Clarmann, T.: ACE-FTS ozone, water vapour, nitrous oxide, nitric acid, and carbon monoxide profile intercomparisons with MIPAS and MLS, J. Quant. Spectrosc. Ra., 186, 63-80, https://doi.org/10.1016/j.jqsrt.2016.06.026, 2017.

Singleton, C. S., Randall, C. E., Chipperfield, M. P., Davies, S., Feng, W., Bevilacqua, R. M., Hoppel, K. W., Fromm, M. D., Manney, G. L., and Harvey, V. L.: 2002-2003 Arctic ozone loss deduced from POAM III satellite observations and the SLIMCAT chemical transport model, Atmos. Chem. Phys., 5, 597609, https://doi.org/10.5194/acp-5-597-2005, 2005.

Singleton, C. S., Randall, C. E., Harvey, V. L., Chipperfield, M. P., Feng, W., Manney, G. L., Froidevaux, L., Boone, C. D., Bernath, P. F., Walker, K. A., McElroy, C. T., and Hoppel, K. W.: Quantifying Arctic ozone loss during the 2004-2005 winter using satellite observations and a chemical transport model, J. Geophys. Res., 112, D07304, https://doi.org/10.1029/2006JD007463, 2007.

Sinnhuber, B. M., Chipperfield, M. P., Davies, S., Burrows, J. P., Eichmann, K. U., Weber, M., von der Gathen, P., Guirlet, M., Cahill, G. A., Lee, A. M., and Pyle, J. A.: Large loss of total ozone during the Arctic winter of 1999/2000, Geophys. Res. Lett., 27, 3473-3476, https://doi.org/10.1029/2000GL011772, 2000 .

Sinnhuber, B.-M., Stiller, G., Ruhnke, R., von Clarmann, T., Kellmann, S., and Aschmann, J.: Arctic winter 2010/2011 at the brink of an ozone hole, Geophys. Res. Lett., L24814, https://doi.org/10.1029/2011GL049784, 2011.

Solomon, S., Garcia, R. R., Rowland, F. S., and Wuebbles, D. J.: On the depletion of Antarctic ozone, Nature, 321, 755-758, 1986.

Solomon, S.: Stratospheric ozone depletion: a review of concepts and history, Rev. Geophys., 37, 275-316, 1999.

Spang, R., Hoffmann, L., Müller, R., Grooß, J.-U., Tritscher, I., Höpfner, M., Pitts, M., Orr, A., and Riese, M.: A climatology of polar stratospheric cloud composition between 2002 and 2012 based on MIPAS/Envisat observations, Atmos. Chem. Phys., 18, 5089-5113, https://doi.org/10.5194/acp-18-5089-2018, 2018.

Steele, H. M., Hamill, P., McCormick, M. P., and Swissler, T. J.: The formation of polar stratospheric clouds, J. Atmos. Sci., 40, 2055-2067, 1983.

Tegtmeier, S., Rex, M., Wohltmann, I., and Krüger, K.: Relative importance of dynamical and chemical contributions to Arctic wintertime ozone, Geophys. Res. Lett., 35, L17801, https://doi.org/10.1029/2008GL034250, 2008.

Tilmes, S., Müller, R., Grooß, and McKenna, D. S.: Calculation of chemical ozone loss in the Arctic winter 1996-1997 us- ing ozone-tracer correlations: Comparison of Improved Limb Atmospheric Spectrometer (ILAS) and Halogen Occultation Experiment (HALOE) results, J. Geophys. Res., 108, 4045, https://doi.org/10.1029/2002JD002213, 2003.

Tilmes, S., Müller, R., Grooß, J.-U., and Russell III, J. M.: Ozone loss and chlorine activation in the Arctic winters 1991-2003 derived with the tracer-tracer correlations, Atmos. Chem. Phys., 4, 2181-2213, https://doi.org/10.5194/acp-4-2181-2004, 2004.

Tilmes, S., Müller, R., Engel, A., Rex, M., and Russell III, J.: Chemical ozone loss in the Arctic and Antarctic stratosphere between 1992 and 2005, Geophys. Res. Lett., 33, L20812, https://doi.org/10.1029/2006GL026925, 2006.

Toon, O. B., Hamill, P., Turco, R. P., and Pinto, J.: Condensation of $\mathrm{HNO}_{3}$ and $\mathrm{HCl}$ in the winter polar stratosphere, Geophys. Res. Lett., 13, 1284-1287, 1986.

Velazco, V. A., Toon, G. C., Blavier, J.-F. L., Kleinböhl, A., Manney, G. L., Daffer, W. H., Bernath, P. F., Walker, K. A., and Boone, C.: Validation of the Atmospheric Chemistry Experiment by noncoincident MkIV balloon profiles, J. Geophys. Res., 116, D06306, https://doi.org/10.1029/2010JD014928, 2011.

von der Gathen, P., Rex, M., Harris, N. R. P., Lucic, D., Knudsen, B. M., Braathen, G. O., de Backer, H., Fabian, R., Fast, H., Gil, M., Kyrö, E., Mikkelsen, I. S., Rummukainen, M., Stähelin, J., and Varotsos, C.: Observational evidence for chemical ozone depletion over the Arctic in winter 1991-92, Nature, 375, 131-134, 1995.

von Hobe, M., Bekki, S., Borrmann, S., Cairo, F., D’Amato, F., Di Donfrancesco, G., Dörnbrack, A., Ebersoldt, A., Ebert, M., Emde, C., Engel, I., Ern, M., Frey, W., Genco, S., Griessbach, S., Grooß, J.-U., Gulde, T., Günther, G., Hösen, E., Hoffmann, L., Homonnai, V., Hoyle, C. R., Isaksen, I. S. A., Jackson, D. R., Jánosi, I. M., Jones, R. L., Kandler, K., Kalicinsky, C., Keil, A., Khaykin, S. M., Khosrawi, F., Kivi, R., Kuttippurath, J., Laube, J. C., Lefèvre, F., Lehmann, R., Ludmann, S., Luo, B. P., Marchand, M., Meyer, J., Mitev, V., Molleker, S., Müller, R., Oelhaf, H., Olschewski, F., Orsolini, Y., Peter, T., Pfeilsticker, K., Piesch, C., Pitts, M. C., Poole, L. R., Pope, F. D., Ravegnani, F., Rex, M., Riese, M., Röckmann, T., Rognerud, B., Roiger, A., Rolf, C., Santee, M. L., Scheibe, M., Schiller, C., Schlager, H., Siciliani de Cumis, M., Sitnikov, N., Søvde, O. A., Spang, R., Spelten, N., Stordal, F., Suminska-Ebersoldt, O., Ulanovski, A., Ungermann, J., Viciani, S., Volk, C. M., vom Scheidt, M., von der Gathen, P., Walker, K., Wegner, T., Weigel, R., Weinbruch, S., Wetzel, G., Wienhold, F. G., Wohltmann, I., Woiwode, W., Young, I. A. K., Yushkov, V., Zobrist, B., and Stroh, F.: Reconciliation of essential process parameters for an enhanced predictability of Arctic stratospheric ozone loss and its climate interactions (RECONCILE): activities and results, Atmos. Chem. Phys., 13, 92339268, https://doi.org/10.5194/acp-13-9233-2013, 2013.

Waters, J. W., Froidevaux, L., Harwood, R. S., Jarnot, R. F., Pickett, H. M., Read, W. G., Siegel, P. H., Cofield, R. E., Filipiak, M. J., Flower, D. A., Holden, J. R., Lau, G. K., Livesey, N. J., Manney, G. L., Pumphrey, H. C., Santee, M. L., Wu, D. L., Cuddy, D T., Lay, R. R., Loo, M. S., Perun, V. S., Schwartz, M. J., Stek, P. C., Thurstans, R. P., Boyles, M. A., Chandra, K. M., Chavez, M. C., Chen, G.-S., Chudasama, B. V., Dodge, R., Fuller, R. A., Girard, M. A., Jiang, J. H., Jiang, Y., Knosp, B. W., LaBelle, R. C., Lam, J. C., Lee, K. A., Miller, D., Oswald, J. E., Patel, N. C., Pukala, D. M., Quintero, O., Scaff, D. M., Van Snyder, 
W., Tope, M. C., Wagner, P. A., and Walch, M. J.: The Earth observing system microwave limb sounder 868 (EOS MLS) on the aura Satellite, IEEE T. Geosci. Remote Sens., 44, 1075-1092, https://doi.org/10.1109/TGRS.2006.873771, 2006.

Waymark, C., Walker, K. A., Boone, C. D., and Bernath, P. F.: ACEFTS version 3.0 data set: validation and data processing update, Ann. Geophys., 56, https://doi.org/10.4401/ag-6339, 2013.

Weber, M., Dhomse, S., Wittrock, F., Richter, A., Sinnhuber, B.-M., and Burrows, J. P.: Dynamical control of $\mathrm{NH}$ and $\mathrm{SH}$ winter/spring total ozone from GOME observations in 1995-2002, Geophys. Res. Lett., 30, 1583, https://doi.org/10.1029/2002GL016799, 2003.

WMO (World Meteorological Organization): Scientific Assessment of Ozone Depletion: 2006, Global Ozone Res., and Monit. Proj. Rep. 50, Geneva, Switzerland, 2006.

WMO (World Meteorological Organization): Scientific Assessment of Ozone Depletion: 2010, Global Ozone Res., and Monit. Proj. Rep. 52, Geneva, Switzerland, 2011.

WMO (World Meteorological Organization): Scientific assessment of ozone depletion: 2014, Global Ozone Res., and Monit. Proj. Rep. 55, Geneva, Switzerland, 2014.
Wohltmann, I. and Rex, M.: The Lagrangian chemistry and transport model ATLAS: validation of advective transport and mixing, Geosci. Model Dev., 2, 153-173, https://doi.org/10.5194/gmd-2153-2009, 2009.

Wohltmann, I., Lehmann, R., and Rex, M.: The Lagrangian chemistry and transport model ATLAS: simulation and validation of stratospheric chemistry and ozone loss in the winter 1999/2000, Geosci. Model Dev., 3, 585-601, https://doi.org/10.5194/gmd-3585-2010, 2010.

Wohltmann, I., Wegner, T., Müller, R., Lehmann, R., Rex, M., Manney, G. L., Santee, M. L., Bernath, P., Suminska-Ebersoldt, O., Stroh, F., von Hobe, M., Volk, C. M., Hösen, E., Ravegnani, F., Ulanovsky, A., and Yushkov, V.: Uncertainties in modelling heterogeneous chemistry and Arctic ozone depletion in the winter 2009/2010, Atmos. Chem. Phys., 13, 3909-3929, https://doi.org/10.5194/acp-13-3909-2013, 2013.

Wohltmann, I., Lehmann, R., and Rex, M.: A quantitative analysis of the reactions involved in stratospheric ozone depletion in the polar vortex core, Atmos. Chem. Phys., 17, 10535-10563, https://doi.org/10.5194/acp-17-10535-2017, 2017. 